CUADERNOS DE ESTUDIOS GALLEGOS, LXIV Núm. 130 (enero-diciembre 2017), págs. 49-89

ISSN: 0210-847X

DOI: $10.3989 /$ ceg.2017.130.02

\title{
O POSICIONAMENTO DA ARISTOCRACIA GALEGA NAS CRISES SUCESSÓRIAS DA SEGUNDA METADE DO SÉCULO X NO REINO DE LEÃO (951-982)
}

\author{
José AleXANDRe Sousa \\ Universidade de Lisboa \\ ORCID iD: http://orcid.org/0000-0003-2475-6665
}

Copyright: (C) 2017 CSIC. Este es un artículo de acceso abierto distribuido bajo los términos de una licencia de uso y distribución Creative Commons Attribution (CC-by) España 3.0.

Cómo citar/Citation: José Alexandre SousA, "O posicionamento da aristocracia galega nas crises sucessórias da segunda metade do século X no reino de Leão (951-982)", Cuadernos de Estudios Gallegos, 64, núm. 130 (2017), págs. 49-89, DOI: http://dx.doi.org/10.3989/ceg.2017.130.02 


\section{O POSICIONAMENTO DA ARISTOCRACIA GALEGA NAS CRISES SUCESSÓRIAS DA SEGUNDA METADE DO SÉCULO X NO REINO DE LEÃO (951-982)}

RESUMO

Neste artigo pretendemos analisar o papel dos membros mais relevantes da aristocracia galega nos diversos episódios da sucessão régia entre a morte de Ramiro II (951) e a sagração real de Bermudo II na catedral de Santiago em 982.

Este período marca de forma indelével a capacidade política, social e militar dos membros das Casas condais galegas num ambiente de franca degradação da autoridade régia, em disputa com a aristocracia das outras geografias que compunham o reino astur-leonês.

Iremos observar, através de um olhar atento das fontes escritas, documentais e narrativas, que o que chama mais à atenção é ambiguidade do posicionamento dos diversos condes em relação aos vários momentos de tensão com os membros da monarquia. Essa ambiguidade assenta na dependência em relação ao monarca para a manutenção e eventual aumento das respectivas propriedades e privilégios, num contexto de regressão territorial proporcionado pela dinâmica muçulmana implementada pelo hachib do califa Hisam II, Abu Amir.

Palavras chave: Aristocracia galega, Ordonho III, Sancho I, Ordonho IV, Ramiro III, Bermudo II.

\section{EL POSICIONAMIENTO DE LA ARISTOCRACIA GALLEGA EN LAS CRISIS DE SUCESIÓN EN LA SEGUNDA MITAD DEL SIGLO X EN EL REINO DE LEÓN (951-982) RESUMEN}

Este artículo tiene como objetivo analizar el papel de los miembros más importantes de la aristocracia gallega en los varios episodios de la sucesión real entre la muerte de Ramiro II (951) y la consagración real de Vermudo II en la catedral de Santiago en 982.

Este período marca de uma forma indeleble capacidad política, social y militar de los miembros de las Casas condales galegas em un ambiente de grande degradación de la autoridade real, en disputa con la aristocracia de las otras geografías que formaban el reino asturleonés.

Vamos a ver, a través de una mirada cercana a las fuentes escritas, el documental y narrativas, que lo que más llama la atención es la ambigüedad del posicionamento de los diversos condes em en relación a los diversos momentos de tensión con los miembros de la monarquía. Esta ambiguedad se basa en la dependencia del monarca para el mantenimiento y posible aumento de sus respectivas propiedades y privilégios, en un contexto de regresión territorial proporcionada por la dinámica musulmana implementado por el hachib del califa Hisam II, Abu Amir.

Palabras clave: Aristocracia gallega, Ordoño III, Sancho I, Ordoño IV, Ramiro III, Vermudo II.

\section{THE POSITIONING OF THE GALICIAN ARISTOCRACY IN THE SUCCESSION CRISES OF THE SECOND HALF OF THE $10^{\mathrm{TH}}$ CENTURY IN THE KINGDOM OF LEON (951-982)}

ABSTRACT

In this article we intend to analyze the role of the most important members of the Galician aristocracy in the various episodes of the royal succession between the death of Ramiro II (951) and the royal consecration of Bermudo II in the cathedral of Santiago in 982.

This period marks indelibly the political, social and military capacity of the members of the Galician aristocratic houses in an environment of frank degradation of the royal authority, in dispute with the aristocracy of the other geographies that composed the astur-leonese kingdom.

We will observe, through an attentive look at the written sources, both documents and narratives, that what is most striking is the ambiguity of the position of the several counts in relation to the various moments of tension with the members of the monarchy. This ambiguity is based on the dependence on the monarch for the maintenance and eventual increase of their respective properties and privileges, in a context of territorial regression provided by the Muslim dynamics implemented by the hachib of the caliph Hisam II, Abu Amir.

KEY words: Galician Aristocracy, Ordonho III, Sancho I, Ordonho IV, Ramiro III, Bermudo II. 
Recibido/Received: 08/03/2017

Aceptado/Accepted: 08/05/2017

$\mathrm{O}$

s acontecimentos que nos irão ocupar nos próximos parágrafos e de acordo com as leituras permitidas pelas fontes cronísticas e documentais, possuem o seu epicentro na dinâmica da sucessão régia, fruto, sem dúvida, da ausência de um mecanismo plenamente uniforme e institucional de regulação das aspirações à potestas regia, particularmente, mas não só, dos infantes. No entanto, e como sabemos, todas essas aspirações são secundadas por interesses particulares dos vários grupos linhagísticos aparentados, maioritariamente por via matrimonial, com essas personagens, na via em que, o destino da família estaria ligado à ascensão, ou não, do seu candidato.

Se face à crescente complexização social e estrutural do reino asturiano, particularmente após Afonso II, diferentes mecanismos vigentes na monarquia goda, nomeadamente legais, irão ser adoptados, e sobre os quais não possuímos grandes dúvidas, já em relação à sucessão régia, e ao contrário do que preconiza Sanchéz-Albornoz ${ }^{1}$, levantam-se algumas questões.

Nas monarquias góticas, como sabemos, a sucessão régia processava-se por eleição, de entre os melhores candidatos e com provas dadas na condução de diferentes assuntos, nomeadamente militares. Tanto podia recair nos filhos do monarca falecido como em outros protagonistas. Sanchéz-Albornoz, na senda do eventual goticismo do reino astur-leonês, defendia o mecanismo da eleição régia, embora, exímio conhecedor dos diferentes e variados acontecimentos em volta dessas mesmas sucessões, abriria algumas excepções nessa linha de pensamento.

Com razão, Isla Frez ${ }^{2}$ aponta que, face à história evidenciada pelas informações que nos chegaram, continua a ser bastante complicado percebermos os mecanismos (se é que os houve) que regulariam a sucessão dos reis e o papel neles desempenhado por filhos, irmãos, primos e sobrinhos, pois, ao longo do

\footnotetext{
1 Entre os muitos artigos por si escritos onde aborda, ainda que indirectamente ou em contexto, este assunto, assinale-se: Claudio SÁnchez-Albornoz, "La Sucesión al Trono de los Reinos de León y Castilla", in Viejos y Nuevos Estudios sobre las Instituiciones Medievales Españolas, Tomo II, $2^{\mathrm{a}}$ edição, Madrid, Espasa-Calpe, 1976, págs. 1107-1165.

2 Amancio Isla Frez, Realezas Hispánicas del Año Mil, Sada, Ediciós do Castro, 1999, pág. 13.
} 
séc. X aparentemente nenhuma ordem estaria subjacente a tal mecanismo e as fontes não autorizam a solidificar a opinião de Albornoz.

Outro dado a ter em conta na nossa análise e transversal à totalidade das diferentes geografias do reino é o labirinto constituído pelas alianças matrimoniais e redes de parentesco com vista à consolidação territorial e política dos diversos grupos aristocráticos. De facto, a pouco linear sucessão dos monarcas astur-leoneses será recorrentemente incomodada por esses grupos que se posicionam para, não só defenderam o seu património actual, mas principalmente garantirem assim a capacidade de influenciar o novo monarca na óptica dos seus interesses particulares.

Para então nos balizarmos e evitar uma dispersão demasiado prolongada por geografias relativamente distantes do objecto de estudo destas linhas, iremos acompanhar, sempre que possível, as acções dos condes galegos Rodrigo Vasques (?-978), Gonçalo Mendes (?-1001) e Gonçalo Moniz (?-981), e respectivos entornos familiares, nas vicissitudes políticas do reino de Leão, desde a morte de Ramiro II em 951 até, grosso modo, ao advento do reinado de Bermudo II em 982.

Estas balizas cronológicas assentam num período bastante fértil de contestação nobiliárquica, não necessariamente agrupada em blocos coesos e uniformes, mas antes, na prossecução de objectivos particulares conjunturais e, com as devidas cautelas, assentando numa dinâmica claramente feudal. É o período em que os actores políticos se multiplicam face à fragilidade da coroa neste contexto de forte disputa, abrindo posteriormente caminho a um progressivo isolamento das famílias condais do Ocidente, particularmente de Portucale e de Coimbra, face à emergência da dinastia de Navarra, na pessoa de Fernando Magno.

Essas disputas, ou melhor dizendo, a capacidade de alimentar e sustentar essas dissensões, quer com a coroa, quer entre as diferentes famílias, assentam na capacidade de mobilização militar por parte dos condes, mobilização essa permitida pelo suporte económico que advém do rol de propriedade sob administração familiar. No entanto, para a geografia e a cronologia em apresso foram raros os encontros bélicos entre exércitos condais e exércitos suportados pela coroa, preferindo-se, pelo menos numa ocasião transmitida pelas fontes, outro tipo de abordagem ${ }^{3}$.

Para além dos exércitos condais, o rei possuiria igualmente as suas tropas, os militibus palatii, no entanto, não deixaria de contar com a mobilização das tropas condais que seriam convocados para o efeito, no sentido de debelar uma potencial ameaça, quer interna, quer externa. A falta de comparência face a essa

\footnotetext{
3 Estamos aqui a fazer menção ao assassinato do então rei Sancho I. Adiante, iremos detalhar este episódio único da história política do reino leonês.
} 
mobilização geralmente acarretava a insubmissão e a ira régia, demonstrada no eventual confisco de propriedades aos faltosos.

\section{OS PROTAGONISTAS}

O estudo dessas famílias e respectivas linhagens, nomeadamente das mais destacadas, já se encontra relativamente bem fundamentado ${ }^{4}$, no entanto, e até por uma questão de enquadramento, não poderíamos deixar de referir, de uma forma simples, o percurso familiar das personagens que pretendemos acompanhar de seguida e que, de certa forma, irão explicar o seu comportamento face às vicissitudes em torno da sucessão régia.

Ao seu tempo, como veremos, Rodrigo Vasques, cabeça da respectiva linhagem, seria um dos mais influentes condes galegos dos meados do séc. X, com património disseminado um pouco por toda a actual Galiza, mas concentrando-se maioritariamente na actual província de Ourense, a Norte do actual Portugal ${ }^{5}$.

Relativamente aos seus ascendentes, os mesmos encontram-se claramente identificados através de um documento presente no Tumbo de Celanova ${ }^{6}$, em que o mesmo refere ser Rodrigo Vasques, filho de Velasco Rodrigues e de Trudilde, que por sua vez, em linha paterna, neto de um outro Rodrigo e de Velasquida.

\footnotetext{
4 Para enquadramento genérico ver: Ermelindo Portela Silva e Maria C. Pallares Méndez, "Elementos para el Análisis de la Aristocracia Altomedieval de Galicia: parentesco y Patrimonio", Studia Historica - Historia Medieval, núm. 5 (1987), págs. 17-32; Margarita Torres Sevilla-QuiÑones de León, Linajes nobiliarios en León y Castilla: Siglos IX-XIII, Salamanca, Junta de Castilla y León, 1999 e para um olhar pormenorizado e interpretativo consultar: Emilio SÁEZ, "Notas al Episcopologio Minduniense del siglo X”, Hispania, núm. XXX (1948), págs. 7-83 e Emilio SÁEz, "Los Ascendientes de San Rosendo. Notas para el estudio de la Monarquia Astur-Leonesa durante los siglos IX y X”, Hispania, núm. XXII (1947), págs. 7-133. Seguiremos igualmente os esquemas genealógicos propostos por Vicente Álvarez PALENZUELA em "La Nobleza del Reino de León en la Alta Edad Media", em El Reino de León en la Alta Edad Media, vol. VII, León, Centro de Estudios e Investigación "San Isidoro", 1995 (Fuentes y estudios de historia leonesa), págs. 297-329 e que se encontram, com algumas adaptações, no final do presente artigo.

5 São várias as fontes documentais, nomeadamente doações, que fazem referência a todo este património e que seguem citadas em diferentes obras que, directa ou indirectamente, analisam esta personagem, respectivo entorno familiar e enquadramento histórico. Por ausência de tempo e igualmente de propósito não compilamos todas estas notícias que certamente nos permitiriam conhecer melhor a implantação regional desta família. A título de exemplo: Amancio Isla Frez, Ejército, Sociedad y Política en la Península Ibérica entre los Siglos VII y XI, Madrid, Ministerio de Defensa-Consejo Superior de Investigaciones Científicas, 2010, págs. 189-192; Amancio Isla Frez, La Sociedad Gallega en la Alta Edad Media, Madrid, Consejo Superior de Investigaciones Científicas, 1992, págs. 120-170; M. Rubén GARcía Álvarez, "Un Documento Interesante para la Historia de Galicia", Cuadernos de Estudios Gallegos, tomo XIX, núm. 59 (1964), págs. 355-368 e M. Rubén GARCíA Álvarez, "La Batalla de Aguioncha: Una guerra civil galaico-portuguesa del siglo X”, Bracara Augusta, Tomo XX, fascículos 45-46 (1967), págs. 13-16.

6 Documento 460, 11 de Setembro de 931 in José Miguel Andrade Cernadas, O Tombo de Celanova: Estudio Introductorio, Edición e Índices (ss. IX-XIII), Santiago de Compostela, Consello de Cultura Galega, 1995, Tomo 1, pág. 633.
} 
Sobre estes últimos ascendentes sobram algumas dúvidas quanto à respectiva filiação, pois e neste caso, as fontes documentais não nos permitem efectuar a devida conjectura com a fiabilidade desejada. No entanto, alguns autores avançam para uma hipotética relação de parentesco com o presor de Coimbra, Hermenegildo Guterres e a sua esposa, Ermesenda Gatones, baseados, novamente tendo por fonte documentação de Celanova ${ }^{7}$, num conjunto de confirmantes em que se destacam alguns filhos desse conde (Guttier e Arias Menendiz) e onde se encontra mencionado, a eles associado, um certo Rodericus Menendiz.

Segundo a opinião de $\mathrm{Saéz}^{8}$, nada na documentação autoriza a estabelecer uma sólida relação entre esse personagem e Hermenegildo Guterres, somente tendo por base o respectivo patronímico a essa proposta. Posteriormente, e na nossa opinião, sem a devida fundamentação, García Álvarez ${ }^{9}$ estabelece a relação filial entre todos estes magnates. No entanto, e quanto nos é possível rastrear na documentação, a ascendência de Rodrigo Vasques remontará somente ao seu avô $\operatorname{Vasco}^{10}$ que, e de acordo com o documento ${ }^{11}$ que temos vindo a seguir, estaria casado com Velasquida, parentes nostri Rudericus et Uelasquida, cuja filiação desconhecemos igualmente.

Para além de Rodrigo, Vasco Rodrigues e Trudilde tiveram outro filho, Ordonho Vasques, que por sua vez, contraiu matrimónio com Ermesenda Guterres, filha de Guterre Osores e Aldonça Mendes e neta, pela via materna, de Hermenegildo Guterres e Ermesenda Gatones, e pela via paterna, de Osório Guterres, irmão de Hermenegildo, seu tio avô.

Em relação ao nosso protagonista, Rodrigo Vasques, o mesmo estaria casado, em primeiras núpcias, com Adosinda Gunteriguiz, filha de Gunterigo Arias e de Gontroda Gonçalves e neta, pela via paterna, de Arias Mendes e de Ermesenda Gondesendes, remontando estes ascendentes a Hermenegildo Guterres, pela via masculina, e a Gatão, conde do Bierzo, pela via feminina. Pela via materna, Adosinda seria neta de Gonçalo Betotes e de Teresa Eriz.

Posteriormente, e aquando da morte de Adosinda, provavelmente antes de $960^{12}$, Rodrigo casará em segundas núpcias com Onega Lucides, filha de Lucídio

\footnotetext{
7 Documento 576, 18 de Agosto de 916 in J. M. Andrade Cernadas, O Tombo de Celanova..., Tomo II, págs. 794-795.

8 E. SÁEz, "Los Ascendientes...", pág. 26, nota 44.

9 M. R. García Álvarez, "Un Documento Interesante...”, pág. 359.

${ }^{10}$ Vicente Álvarez Palenzuela admite, com base na filiação patronímica não galega, que este ascendente de Rodrigo Vasques possa ter vindo com o irmão de Afonso III, Bermudo, aquando do seu retiro na região centro, a par de Diogo Fernandes, entre outros. Vicente Álvarez Palenzuela, "La Nobleza del Reino de León...”, págs. 212-213.

${ }^{11}$ Documento 460, 11 de Setembro de 931 in J. M. Andrade Cernadas, O Tombo de Celanova..., Tomo II, pág. 633 .

12 M. R. García Álvarez, “La Batalla de Aguioncha...”, pág. 15.
} 
Alvites e de Ximena, por sua vez neta, pela via masculina, de Alvito Lucides e Munia Dias, remontado a sua ascendência ao primeiro presor de Portucale (Vímara Peres) e a Diogo Fernandes, companheiro de um irmão de Afonso III, o infante Bermudo, no seu retiro em terras actualmente portuguesas ${ }^{13}$.

Relativamente à sua descendência, Rodrigo apenas terá filhos da sua primeira mulher ${ }^{14}$, Adosinda, neste caso, Paio Rodrigues, futuro bispo de Compostela, Onega, Mumadona, Trudilde, Aldonça Rodrigues, casada com um membro da descendência da família de Ero Fernandes e Velasquida Rodrigues, que casou igualmente com um membro dessa mesma família.

Faleceu provavelmente antes de Outubro de 978, como atestam as palavras da sua filha Onega, numa doação ao mosteiro de Celanova, ...pater noster dive memoria... ${ }^{15}$.

Como vimos, e apesar da escassez documental para tempos mais recuados, a família de Rodrigo Vasques estaria solidamente implantada na antiga Galiza dando igualmente algum respaldo à proposta de Vicente Álvarez Palenzuela sobre as origens desta linhagem, justificando, deste modo, o enlace, tanto o dele como do seu irmão, bem como, dos seus descendentes, com membros das principais famílias galegas.

Sobre Gonçalo Mendes iremos observar o que já assinalamos nos parágrafos atrás, cruzamento entre membros das várias famílias dominantes, fazendo com que, e por vicissitudes matrimoniais, sejam, de algum modo, parentes uns de outros.

Neste caso, Gonçalo seria membro de uma linhagem que marcaria profundamente as vicissitudes políticas e sociais da Galiza meridional, e de certa forma, condicionando a natureza da relação com o reino de Leão em anos vindouros.

Assim, Gonçalo Mendes seria filho de Mumadona Dias, neto por sua vez de Diogo Fernandes e de Onega pela via feminina, ambos aios de Ramiro II e potestas na região de Viseu e territórios limítrofes. Pelo lado paterno, filho de Hermenegildo Gonçalves e neto de Gonçalo Betotes e de Teresa Eriz, remontando a sua linhagem paterna ao presor de Afonso III, Afonso Betotes.

Gonçalo, tal como Rodrigo Vasques, irá contrair matrimónio por duas vezes. Em primeiras núpcias irá casar-se com Ilduara Pais ${ }^{16}$, Uobis Gunsalbo menendiz

\footnotetext{
${ }^{13}$ Manuel Luís ReAL, "O castro de Baiões terá servido de atalaia ou castelo na Alta Idade Média? Sua provável relação com o refúgio de Bermudo Ordonhes na Terra de Lafões”, Revista da Faculdade de Letras, série Ciências e Técnicas do Património, vol. XII (2013), págs. 203-230.

${ }^{14}$ M. R. García Álvarez em “Un Documento Interessante...”, pág. 363, parece equivocar-se, pois, apresenta filhos de ambas as mulheres de Rodrigo, no entanto, posteriormente em: "La Batalla de Aguioncha...", pág. 15 , menciona somente prole de Adosinda.

15 Documento 481, 23 de Outubro de 978 in J. M. Andrade Cernadas, O Tombo de Celanova..., Tomo II pág. 667.

${ }^{16}$ E. SÁEz, "Notas al Episcopologio...”, pág. 46 e notas 154 e 155 da mesma página.
} 
et uxor tue ilduare e, em data desconhecida, mas seguramente anterior a $983^{17}$, com Ermesenda.

Ilduara Pais era filha de Paio Gonçalves e de Ermesenda Guterres, cujo pai seria irmão de Hermenegildo Gonçalves, pai de Gonçalo. Ilduara seria, portanto, sua prima direita. Em termos de ascendentes, apenas gostaria de ressalvar a sua condição de sobrinha de S. Rosendo, irmão de sua mãe. Da sua segunda esposa, e de momento, não se conhece a sua ascendência.

Relativamente aos seus descendentes, a sua prole adviria unicamente da sua relação com Ilduara que, entre outros filhos, encontrava-se Mendo Gonçalves, futuro tutor e vicarius de Afonso $\mathrm{V}$ e figura de destaque nas vicissitudes políticas de então.

Sobre a data do falecimento de Gonçalo imperam algumas dúvidas. José Mattoso $^{18}$ assinala como hipótese o ano de 997, enquanto García Álvarez ${ }^{19}$ baliza esse facto nos finais de 1001. O que se sabe, ao nível documental, é que Gonçalo Mendes apresenta-se, em conjunto com outras pessoas, na qualidade de juiz a dirimir uma contenda pela posse de uma propriedade rústica, a villa Bidualdi, em Junho de 1001, ... in concilio ante iudicum, comes Gundisaluus Menendi... ${ }^{20}$.

Finalmente, e última personalidade deste triângulo que aqui escolhemos acompanhar, Gonçalo Moniz, o mesmo é descendente de uma família sobejamente conhecida, sendo bisneto em linha directa de Hermenegildo Guterres, e cuja implantação regional se situa maioritariamente a Sul do Douro. Ressalvando, no entanto, que o património da estirpe familiar se encontraria disperso por várias geografias do reino astur-leonês, nomeadamente, Galiza e Leão ${ }^{21}$.

Gonçalo seria filho de Munio Guterres e de Elvira Arias e, tal como seus pais, viria a casar com uma prima direita, Tutadomna Froilaz, filha por sua vez de Fruela

\footnotetext{
17 Pois será desse ano que encontramos na documentação uma menção explícita a este facto, ...mea conjux Ermisinda ..., Documento CXXXVIII in Portugalia Monumenta Historica, Diplomata et Chartae, I, Academia das Ciências de Lisboa, págs. 84-87.

18 José Matroso, “As Famílias Condais Portucalenses dos Séculos X e XI”, in A Nobreza Medieval Portuguesa. A Familia e o Poder, Lisboa, Editorial Estampa, 1981, págs. 145-146.

19 M. R. García Álvarez, "La Batalla de Aguioncha...”, pág. 12. No entanto, o autor argumenta que a data provável da sua morte se entende balizada entre Junho de 1001 e Janeiro de 1002, pois, e seguindo a argumentação do autor, será num documento de Celanova, datado precisamente de 11 de janeiro de 1002 , que o seu filho, Mendo Gonçalves, o dá como falecido. Mas olhando com atenção o referido documento, apenas nele observamos Menendus dux prolis Gundisalviz, o que nos levanta algumas dúvidas. O que é certo é a ausência de Gonçalo Mendes da documentação após Junho de 1001.

${ }^{20}$ Documento 132, 5 de Junho de 1001 in Pilar Loscertales de Valdeavellano, Tumbos del Monasterio de Sobrado de los Monjes, vol. I, Tumbo Primero, Madrid, Dirección General del Patrimonio Artístico y Cultural-Archivo Histórico Nacional, 1976, pág. 167.

${ }^{21}$ De acordo com documentação vária presente maioritariamente no cartório de Sahagún, observamos Gonçalo Moniz actuando, em diversas ocasiões, na gestão desse património imobiliário.
} 
Guterres e de Sarracina. Relativamente à sua descendência, e de acordo com José Mattoso $^{22}$, Gonçalo e Tutadomna teriam tido quatro filhos, sendo o primogénito Froila Gonçalves aquele que viria a ter maior protagonismo nas vicissitudes políticas de seu tempo, como cabeça da sua linhagem e herdeiro do condado de Coimbra sob domínio muçulmano.

A última menção documental onde aparece é como subscritor de uma doação particular ao mosteiro de Lorvão em Dezembro de $981^{23}$.

\section{A SUCESSÃo DE RAMIRO II}

Tal como se enunciou linhas atrás, iríamos, até por uma questão de melhor contextualizar as acções dos vários condes aqui trazidos, procurar observar algumas vicissitudes que caracterizaram o reino de Leão neste período, nomeadamente aquelas que se revelaram estruturantes para o Ocidente do reino.

O nosso ponto de partida, aparentemente paradoxal, será olhar, ainda que de forma ligeira, para Oriente, em direcção a terras castelhanas e à política ali implementada por Ramiro II no rescaldo da vitória de Simancas e do subsequente processo expansivo para Sul e que explicam, em parte, e na nossa opinião, alguns dos acontecimentos posteriores levados à acção em terras Ocidentais, nomeadamente na Galiza e em Leão.

Desde cedo Ramiro II compreendeu a importância de conter a expansão geográfica e a consequente influência política do condado de Castela e dos respectivos condes, neste caso, de Fernão Gonçalves, e tendo em conta todas as implicações da vitória de Simancas, irá constituir o condado de Monzón, situado precisamente entre os condados de Saldanha e de Castela. A sua gestão irá ser confiada a Ansur Fernandes, que nas palavras póstumas do seu filho Fernando, seria um seu partidário e leal servidor, ...Assuri comite satis fidelissimum fuise domino Rademiro principe... ${ }^{24}$.

\footnotetext{
22 Segundo José Mattoso existem duas personalidades, Froila e Veila Gonçalves, citadas na documentação que poderão ser a mesma pessoa. J. MAтToso, “As Famílias Condais...”, pág. 124. Opinião contrária tem Rui Pinto de Azevedo que defende, apesar da escassez documental, que Froila e Veila seriam duas pessoas distintas. Rui Pinto de Azevedo, "A expedição de Almançor a Santiago de Compostela em 997, e a de piratas normandos à Galiza em 1015-16”, Revista Portuguesa de História, Tomo XIV (1973), págs. 81-82, concretamente a nota 17 da pág. 81.

${ }^{23}$ Documento CXXXIII, Dezembro de 981 in Portugalia Monumenta Historica, Diplomata et Chartae, $I$, pág. 82 .

${ }^{24}$ Documento 285, 25 de Agosto de 976 in José Maria Mínguez, Colección Diplomática del Monasterio de Sáhagun (siglos $I X$ y X), León, Centro de Estudios e Investigación San Isidoro-Archivo Histórico Diocesano de León, 1976 (Fuentes y Estudios de Historia Leonesa, n. 17), pág. 343.
} 
A família de Ansur Fernández é originária de terras castelhanas, chegando o seu pai, Fernando Ansúrez, em 929 a ser designado em documentação proveniente de Cardena como ...comite Fredinando Assuriz in Castella ${ }^{25}$.

No entanto, a par dessa reorganização administrativa e política, Ramiro II, seguindo exemplos anteriores, marcaria igualmente presença, na pessoa do seu filho Sancho, como imperante em terras castelhanas, não sendo certamente alheio o facto de Sancho ser filho de Urraca, sua segunda mulher, de claros ascendentes navarros ${ }^{26}$. Deste modo, Ramiro exerceria uma dupla pressão sobre Castela, uma vez que se estreitavam os laços entre as monarquias leonesa e navarra, que desde logo tentaram diluir o poder dos condes castelhanos da família de Fernão Gonçalves.

Esta política é observável na documentação através de várias formulas notariais que reflectem necessariamente a percepção decorrente da actuação de vários protagonistas na acção política levada a acabo no território castelhano, em que, desde logo, sobressaem Fernão Gonçalves, Ramiro II, quer na pessoa de seu filho Sancho, quer pessoalmente, e igualmente, o conde de Monzón, Ansur Fernandes.

Tendo em conta esse objectivo, e após Maio de $944^{27}$ encontramos com alguma cadência, até pelo menos Novembro de 950, o infante Sancho exercendo imperium em terras castelhanas, ...regnante principe Ranimiro in Obeto, et prolis eius Sancioni in Castella ${ }^{28}$, ainda que nominalmente, pois o infante teria provavelmente pouco mais de 12 anos.

Outro destes protagonistas, neste caso, Ansur Fernandes, localizamo-lo somente em dois documentos de Cardena, no entanto, num deles não deixa de ser sintomático a potestas exercida pelo rei sobre os demais imperantes em terras castelhanas. Observamos em Agosto de 944, ... regnante rex Ranimiro in Legione, et sub eius ymperio comite Assur Fernandiz in Castella ${ }^{29}$, e anteriormente, em Dezembro de 941, ...regnante principe Ranimiro in Legione, et sub eius ymperio comite Fredinando in Castella ${ }^{30}$.

\footnotetext{
${ }_{25}$ Documento CXXXVII, 1 de Outubro de 929 in Luciano Serrano (ed.), Becerro Gótico de Cardena, Valladolid, Cuesta, 1910, págs. 149-150.

${ }^{26}$ Urraca Sanches era filha do rei Sancho Garcés I e da rainha Toda de Pamplona.

27 Encontramos o infante Sancho em data anterior, neste caso, em 943 num documento proveniente do mosteiro de San Millán de la Cogolla, no entanto, nele não se observa traços que revelem uma particular menção ao desempenho de autoridade, ...et testes ad roborandum tradimus: Sancius, ipsius regis filius, confirmans..., in Universidad del País Vasco-Centro Internacional de Investigación de la Lengua Española, Becerro Galicano de San Millán de la Cogolla (em linha), disponível em: < www.ehu.eus/ galicano/id142 > [consultado em 17/01/2017].

${ }^{28}$ Documento CCLXXVII, 8 de Maio de 944 in L. Serrano (ed.), Becerro Gótico de Cardena ..., pág. 294.

${ }^{29}$ Documento LIII, 23 de Agosto de 944 in L. Serrano (ed.), Becerro Gótico de Cardena..., pág. 66.

${ }^{30}$ Documento LI, 23 de Dezembro de 941 in L. Serrano (ed.), Becerro Gótico de Cardena..., págs. 62-63.
} 
De assinalar igualmente, e em claro contraste com o exposto nas linhas anteriores, onde o infante Sancho exerceria com alguma independência, face ao seu pai, a potestas em terras castelhanas, aparecendo isoladamente em vários documentos; em terras gelegas os outros seus filhos, o primogénito Bermudo e Ordonho (futuro Ordonho III), apareceriam ao lado de seu pai na maioria das vezes ${ }^{31}$.

Em resumo, e concluindo este pequeno apontamento fora do quadro cronológico proposto, gostaríamos de referir que os reis leoneses sempre procuraram conter determinados processos que, em certas situações, poderiam degenerar em poder concorrente aos interesses da coroa, e que esses esforços estariam necessariamente escorados no prestígio do monarca, quer militar, quer político, ao estabelecer e manter uma política de equilíbrio entre as várias famílias condais, nas heterogéneas geografias do reino.

Com a morte do rei em 951, e igualmente na ausência física do primogénito (falecido provavelmente em $941^{32}$ ), o outro filho nascido do seu casamento com Adosinda Guterres, Ordonho, irá ascender à dignidade régia com o título de Ordonho III (951-956).

Esta situação, de acordo com a crónica de Sampiro, irá desencadear certos levantamentos aristocráticos, tanto na Galiza como em Castela, num aparente movimento de oposição a essa investidura, sem que se reconheçam, de forma implícita, quais os seus reais objectivos. Assim, podemos ver que, Frater quidem eius nomine Sancius, consilio inito una cum avunculo suo nomine Garsiano rege Pampilonensium, necnon Fredinandus Gundissalvi Burgensium comes, unusquisque cum exercitu suo Legionem accesserunt, qualiter Ordonium a regno expellerent, et Sancium fratrem eius in regno confirmarent, e mais à frente, ... rex Ordonius magno exercitu aggregato Galleciam edomuit... ${ }^{33}$.

Num aparente conjugar de esforços, certos sectores da aristocracia navarra, castelhana e galega, em momentos cronologicamente desfasados, uniram-se contra Ordonho III polarizando o seu apoio (pelo menos a aliança navarra-castelhana) no seu meio-irmão Sancho, filho de D. Urraca, a segunda mulher de Ramiro II, que como vimos linhas atrás, vinha a desempenhar, é certo que com o respaldo da figura de seu pai, um papel central na vida social e política nas terras castelhanas, em contraste com a vida pública levada a cabo pelos restantes filhos de Ramiro II em terras mais Ocidentais.

\footnotetext{
31 Tanto quanto presentemente conhecemos, o primogénito de Ramiro, Bermudo, somente se encontra, ainda que de tenra idade, isoladamente num único documento, neste caso, num documento de doação datado de Dezembro de 937 proveniente do cartório de Lorvão, "Veremudus prolis regis". Documento XLV in Portugalia Monumenta Historica, Diplomata et Chartae, I, pág. 27.

32 Amancio Isla Frez, "Nombres de Reyes y Sucesión al Trono (siglos VIII-X)”, Studia Historica - Historia Medieval, núm. 11 (1993), pág. 31 e V. Álvarez Palenzuela, “La Nobleza del reino de León...”, pág. 207. ${ }_{33}$ Historia Silense, edición preparada por Francisco Santos Coco, Madrid, Sucesores de Rivadeneyra, 1921, págs. 53-54.
} 
Isla Frez ${ }^{34}$ levanta com fundamento certas dúvidas sobre as parcas palavras do clérigo astorgano em relação ao papel de Fernão Gonçalves (que seria sogro de Ordonho pela via do casamento da sua filha Urraca com o então infante) no apoio a Sancho, em articulação com as forças de Navarra, território sempre olhado com suspeita pelos vários condes castelhanos. De acordo com o relato de Sampiro, ao apoiar o infante, cuja actividade política em vida de Ramiro II se centrou na limitação da sua influência, Fernão Gonçalves estaria numa aparente contradição. O que é certo é que o conde castelhano irá desempenhar, anos depois, um papel central na deposição do então rei Sancho I.

Sobre este momento divergente, que levará Ordonho III a debelar com relativo sucesso os vários movimentos bélicos, ...rex Ordonius satis exercitatus stetit, suasque civitates defensavit, et regni sceptra vindicavit... ${ }^{35}$, a nobreza galega terá diferentes posicionamentos.

Sabemos, através de um documento régio presente no cartório de Celanova ${ }^{36}$, que pouco antes do término do seu reinado, Ordonho dirigiu-se a terras galegas, concretamente à zona de Lugo, para debelar uma revolta protagonizada por certos sectores da aristocracia galega. Ximeno Dias e dois dos seus filhos, neste caso, Gonçalo e Bermudo, ...tius noster cognatus vester Scemenus Didaci, quomodo et que suprini vestri nequiter nominati Gundisalvus et Veremudus abuerunt, que pro eorum facimus et execrabili infidelitate caruerunt $^{37}$ e eventualmente Rodrigo Vasques e Bermudo Magnítiz ${ }^{38}$, são os implicados, ...Illud adhuc notabiliter concedimus quod vos de vestra mandatione dederatis ad canis filium et magniti Veremudum, Bollario, Paramo medio et Paratella ad Rodericum ... ${ }^{39}$.

Assim, a 19 de Maio de 955 Ordonho III empenhava-se na restituição da administração de uma série de propriedades ao mosteiro de Celanova, na pessoa de Rosendo, que lhe teriam sido confiadas, em doação, pelo seu pai Guterre Mendes, que por sua vez, teriam sido entregues aos magnates em causa. Pela sua conduta de infidelidade régia e eventual usurpação de direitos, as propriedades deveriam regressar à administração directa de S. Rosendo e do mosteiro

\footnotetext{
34 A. Isla Frez, Realezas Hispánicas del Año Mil..., pág. 30.

${ }^{35}$ Historia Silense, Edición preparada por Francisco Santos Coco, pág. 54.

${ }^{36}$ Documento 54, 19 de Maio de 955 in J. M. Andrade Cernadas, O Tombo de Celanova ..., Tomo I, págs. 86-87.

37 Documento 54, 19 de Maio de 955 in J. M. Andrade Cernadas, O Tombo de Celanova..., Tomo I, pág. 86.

38 V. Álvarez Palenzuela, "La Nobleza del reino de León...”, pág. 213 e M. Rubén García Álvarez, “El Gallego Ordono III, Rey de León”, Cuadernos de Estudios Gallegos, tomo XXII, núm. 68 (1967), pág. 300.

39 Documento 54, 19 de Maio de 955 in J. M. Andrade Cernadas, O Tombo de Celanova..., Tomo I, pág. 86 .
} 
de Celanova, ...ipsa suprataxata hereditas vobis sit concessa et omne ipsa mandatione usque ad mare... ${ }^{40}$.

O percurso pessoal e político de Ximeno Dias já se conhece razoavelmente ${ }^{41}$, o qual podemos observar maioritariamente através da presença documental, identificando-o amiúde entre os acompanhantes de Ramiro II e igualmente pouco depois da entronização do infante Ordonho, onde o acompanha até Santiago ${ }^{42}$. Como já dissemos, a análise documental nada nos informa sobre esta mudança comportamental, no entanto, sobre este assunto vários autores ${ }^{43}$ referiram, entre os nomes já assinalados, o conluio com Gonçalo Moniz, conde de Coimbra.

Ximeno Dias, tal como Mumadona Dias, seria filho de Diogo Fernandes e estaria casado com Ausenda Guterres, por sua vez, filha de Guterre Mendes. Esta via familiar, de união com um membro da estirpe de Hermenegildo Guterres, fazia de Ximeno Dias tio de Gonçalo Moniz, pois, Ausenda era irmã de Munio, pai de Gonçalo.

No entanto, e apesar das ligações familiares existentes entre estes dois nobres com interesses convergentes na região a Sul do Douro ${ }^{44}$, não vislumbramos, nesta questão de oposição e revolta contra a figura régia, uma conexão óbvia entre eles. É certo que posteriormente Gonçalo Moniz irá figurar entre os presentes na documentação de Sancho I e do seu filho Ramiro III; em campo oposto, como veremos, ao do conde portucalense Gonçalo Mendes, sem, no entanto, figurar como um claro opositor de Ordonho III.

Contemporaneamente ao acontecimento retratado linhas atrás, e através da documentação disponível ${ }^{45}$, não conhecemos o percurso político de Gonçalo

\footnotetext{
${ }^{40}$ Documento 54, 19 de Maio de 955 in J. M. Andrade Cernadas, O Tombo de Celanova..., Tomo I, pág. 86 .

${ }^{41}$ Entre outras obras, ver: José Mattoso, “As Famílias Condais...”, págs. 137-138; M. Rubén García Álvarez, "Jimeno Díaz y Adosinda Gutiérrez”, Bracara Augusta, Tomo XXXII, fascículos 73-74 (1978), págs. 143-180 e M. Rubén García Álvarez, "La Reina Velasquita, nieta de Muniadomna Diaz?”, Revista de Guimarães, 70 (1-2) (1960), concretamente págs. 212-219 e nota 56 para percurso documental.

${ }^{42}$ Documento 43, 18 de Maio de 952 in Manuel Lucas Álvarez, Tumbo A de la Catedral de Santiago. Estudio y Edición, Santiago, Seminario de Estudos Galegos-Cabildo de la S.A.M.I. Catedral, 1998, págs. 116-117.

${ }^{43}$ Luís Gonzaga de Azevedo, História de Portugal, vol. II, Lisboa, Edições Bíblion, 1939, págs. 101-102; Paulo MerêA, De Portucale (civitas) ao Portugal de D. Henrique, Porto, Portucalense Editora, 1954, págs. 17-18 e M. Rubén García Álvarez, "El Gallego Ordono III, Rey de León”, Cuadernos de Estudios Gallegos, tomo XXII, núm. 68 (1967), pág. 300.

${ }_{4}$ Mário Gouveia, "Hermenegildo Guterres e a presúria de Coimbra (séc. IX-X)", in Olhares sobre a História. Estudos oferecidos a Iria Gonçalves, Lisboa, Caleidoscópio, 2009, págs. 285-286, concretamente a nota 32, onde observamos o percurso político de Jimeno Dias nessa região. Igualmente, J. MATToso, “As Famílias Condais...”, págs. 139-140.

${ }^{45}$ Levantada por Justiniano Rodríguez em: “Gonzalo Munoz, Dux de Terra Portucalense", in Actas das II Jornadas Luso-Espanholas de História Medieval, vol. I, Porto, Centro de História da Universidade do Porto-Instituto Nacional de Investigação Cientifica, 1987, págs. 111-121.
} 
Moniz. Apenas o vamos encontrar, tal como Ximeno, na companhia de Ordonho III na doação de Munia Dias ao mosteiro de Lorvão em data anterior a $956^{46}$, ou não fosse ele, e restante família, um dos patronos desse mosteiro. Curiosamente, as únicas menções documentais à presença de Gonçalo no séquito do rei anterior, Ramiro II, são precisamente quando o monarca estancia na região de Coimbra e assiste a acções de doação de património a esse mesmo mosteiro ${ }^{47}$.

Existe igualmente outro documento de Ordonho III, datado de Maio de 956, onde podemos encontrar o seu nome entre os vários subscritores. No entanto, e ao contrário de Justiniano Rodríguez ${ }^{48}$, inclinamo-nos para a opinião dos editores da colectânea onde o mesmo se encontra, ou seja, Gonçalo Moniz apenas apensa a sua subscrição à confirmação do mesmo levada a cabo pelo monarca subsequente, Sancho I ${ }^{49}$ e não na companhia de Ordonho III.

Em contraste com esse apartamento do séquito de Ordonho III, vamos localizar Gonçalo em variados diplomas do seu sucessor, tanto após a sua entronização, como aquando do seu regresso de Córdoba. Diplomas esses expedidos de diferentes geografias, como sejam a natural região Coimbrã, mas igualmente, Leão e Sahagún.

Numa sucessão de diplomas régios, começando por uma doação ao mosteiro de Sahagún em Agosto de 957, onde o vemos junto dos filhos de Ximeno Dias, até ao último diploma expedido por Sancho I, lavrado em terras de Lorvão, pouco antes do seu assassinato em Novembro de 966, observamos Gonçalo Moniz quase sempre presente no séquito real. Ao todo, e na nossa contagem, estará presente em sete diplomas régios ${ }^{50}$, maioritariamente em terras leonesas onde teria igualmente propriedades fundiárias ${ }^{51}$.

Para concluirmos, de momento, o percurso de Gonçalo Moniz nesta contenda dinástica, fica a ausência de claros indícios, tanto cronísticos como documentais,

\footnotetext{
${ }^{46}$ Documento C in Portugalia Monumenta Historica, Diplomata et Chartae, I, págs. 63-64. Sobre a datação deste documento ver o que dissemos na nota 522.

47 Documento L, 26 de Janeiro de 943 in Portugalia Monumenta Historica, Diplomata et Chartae, I, págs. 29-30. Data proposta por J. Rodríguez, "Gonzalo Munoz...”, pág. 114 e documento XV in Portugalia Monumenta Historica, Diplomata et Chartae, I, pág. 10 e J. Matroso, “As Famílias Condais...”, pág. 123. 48 J. Rodríguez, “Gonzalo Munoz...”, pág. 114.

49 Documento 295, 5 de Maio de 956 in Emilio Sáez e Carlos Sáez, Colección Documental del Archivo de la Catedral de León (775-1230), II (953-985), León, Centro de Estudios e Investigación San IsidoroArchivo Histórico Diocesano de León, 1990 (Fuentes y Estudios de Historia Leonesa, n. 41), págs. 60-63. ${ }^{50}$ Baseamo-nos basicamente em: J. Rodríguez, "Gonzalo Munoz...”, págs. 111-121; J. Mattoso, "As Famílias Condais...”, págs. 123-124 e E. SÁEZ, "Los Ascendientes de San Rosendo...”, págs. 107-108, concretamente a nota 154 da pág. 107.

51 J. Rodríguez, “Gonzalo Munoz...”, pág. 116 e Documento 255, 4 de Abril de 970 in J. M. Mínguez, Colección Diplomática del Monasterio de Sáhagun..., págs. 300-301, ... ipsas villas Gundisalvo Nunniz que nunc usque iuris obtinuit.
} 
que suportem a tese dos autores já citados atrás em que o conde conimbricence estaria implicado na revolta galega protagonizada por Ximeno Dias, e como tal, somos levados a pensar, na melhor das hipóteses, que a presença efectiva de Gonçalo nos diplomas de Sancho I e a sua ausência do séquito de Ordonho III, não o tornavam num claro simpatizante deste último, sem, no entanto, nos dar garantias da sua participação activa na conspiração.

Outro dos nomes aparentemente implicados na sedição galega que aqui retratamos é o de Rodrigo Vasques, cujo percurso político é bastante revelador da estratégia comum às grandes famílias da aristocracia alto-medieval, ou seja, na ausência de uma regra clara em relação à sucessão régia, essas famílias, e na existência de vários candidatos, balançam o seu apoio naquele que lhes dê garantias suficientes de preservação e eventual ampliação do seu património.

Somente três anos volvidos desde o instável início do reinado de Ordonho III é que iremos encontrar Rodrigo Vasques ao seu lado, neste caso, em três ocasiões documentadas e todas do mesmo ano de 954. Numa doação à igreja de Leão em Junho $^{52}$; num documento interpolado datado de Agosto $^{53}$ e finalmente a 12 de Setembro noutro documento de doação ${ }^{54}$.

Constatamos que Rodrigo, através da análise da totalidade da documentação conhecida de Ordonho III $^{55}$ e ao contrário de outros membros da aristocracia (como, por exemplo, Ansur Fernandes e seu filho Fernando Ansúrez), não se caracterizou como um seu fiel adepto, pois não o voltaremos a encontrar no séquito real após essa última data. E tendo presente o documento que nos está a servir de base para estes parágrafos (o documento de Celanova de 19 de Maio de 955) e apesar do seu nome não se observar explicitamente, a ausência da documentação após Novembro de 944, leva-nos a pensar o que acabamos de expor, ou seja, na sedição galega Rodrigo Vasques será um dos protagonistas, tendo, no entanto, desempenhado um papel aparentemente secundário.

Esta ausência de Rodrigo do séquito de Ordonho III, tanto no início do seu reinado como na parte final do mesmo, irá levar a alguns autores ${ }^{56}$ a defenderem a sua inclusão entre os fideles de Sancho I, no entanto, e apesar do mesmo se encontrar presente em vários documentos deste último rei, temos de reconhecer

\footnotetext{
52 Documento 270, versão “A”, 8 de Junho de 954 in E. SÁEz e C. SÁEz, Colección Documental del Archivo de la Catedral de León..., págs. 19-22.

53 Documento 274, 27 de Agosto e datado pelo respectivo editor da colectânea de 954, in E. SÁEz e C. SÁEz, Colección Documental del Archivo de la Catedral de León..., págs. 28-30.

${ }_{54}$ Documento 45, 12 de Setembro de 954 in M. Lucas Álvarez, Tumbo A de la Catedral de Santiago..., págs. 119-121.

55 Nomeadamente o levantamento efectuado por M. LuCAs Álvarez, “Cancillerías Reales...”, págs. 335 339 e M. R. Garcia Álvarez, "El Gallego Ordono III...”, págs. 311-335.

56 Entre outros, M. R. Garcia Álvarez, "La Batalla de Aguioncha...", pág. 20.
} 
no seu percurso uma certa prudência, pois somente após o regresso de Sancho de Córdoba é que o podemos localizar na sua companhia ${ }^{57}$.

Com um percurso algo semelhante, mas menos linear, que Rodrigo Vasques nestes últimos acontecimentos, encontramos Bermudo Magnítiz, o último nome implicado na sedição contra o rei.

Tirando as notas documentais que iremos referir, pouco de concreto se conhece sobre este nobre galego ${ }^{58}$, no entanto, e antes de avançarmos, importa mencionar que, e na percepção de Ordonho III, será o seu pai Magniti Bermudes um dos responsáveis por esta revolta, ...Illud adhuc notabiliter concedimus quod vos de vestra mandatione dederatis ad canis filium et magniti Veremudum ... ${ }^{59}$. O percurso que irá seguir o seu filho permite-nos suspeitar da sua cumplicidade.

Algum tempo antes desses eventos, mais concretamente a 19 de Fevereiro de 951, encontramos Bermudo Magnítiz a desempenhar um cargo curial, pois será na qualidade de maiordomus que irá subscrever o primeiro documento de Ordonho $\mathrm{III}^{60}$. Depois dessa data apenas o voltaremos a localizar nos mesmos documentos onde se encontra igualmente presente Rodrigo Vasques, ou seja, a 8 de Junho de 954 e a 12 de Setembro do mesmo ano ${ }^{61}$.

Já no reinado de Sancho I, e quando ainda se procurava uma certa consolidação da figura real, penso que será significativo a sua assinatura constar como primeiro subscritor de uma importante doação de direitos económicos ao mosteiro de Sahagún, lavrada em Agosto de 95762. No entanto, já com Sancho no exílio em Córdoba e reinando Ordonho IV, Bermudo Magnítiz aparentemente muda

\footnotetext{
${ }^{57} \mathrm{Na}$ documentação de Sancho I anterior ao levantamento dos magnates palatii e dos comites gallecos que o forçaram ao exílio, não encontramos Rodrigo Vasques entre os respectivos confirmantes, somente o vemos pela primeira vez ao lado de Sancho I num documento do mosteiro de Celanova, Documento 356, 28 de Março de 959 in J. M. Andrade Cernadas, O Tombo de Celanova..., Tomo I, págs. 512-513. No entanto, M. Rubén Garcia Álvarez afirma que Rodrigo encontra-se entre os subscritores do seu primeiro documento lavrado enquanto rei, uma doação a Santiago de 13 de Novembro de 956. Nela apenas encontramos um Rudericus, sem qualquer referência a patronímico ou a qualquer outra pista que nos indique tratar-se, com segurança, de Rodrigo Vasques. M. Rubén Garcia Álvarez, "Ordono IV de León, un rey impuesto por Castilla”, Archivos Leoneses, núm. 42, Julio-Diciembre (1967), pág. 10.

58 M. R. Garcia Álvarez, "El Gallego Ordono III...”, pág. 300.

59 Documento 54, 19 de Maio de 955 in J. M. Andrade Cernadas, O Tombo de Celanova ..., Tomo I, pág. 86 .

${ }^{60}$ Documento 426, 19 de Fevereiro de 951 in J. M. Andrade Cernadas, O Tombo de Celanova ..., Tomo I, págs. 586-587, "Veremudus Magniti et maiordomus".

${ }^{61}$ Documento 270, versão "A”, 8 de Junho de 954 in E. SÁEz e C. SÁEz, Colección Documental del Archivo de la Catedral de León..., págs. 19-22 e Documento 45, 12 de Setembro de 954 in M. LuCAs Álvarez, Tumbo A de la Catedral de Santiago..., págs. 119-121, respectivamente.

${ }^{62}$ Documento 155, 19 de Agosto de 957 in J. M. Mínguez, Colección Diplomática del Monasterio de Sáhagun ..., págs. 194-195. Ao lado de Bermudo Magnítiz encontramos os já citados filhos de Ximeno Dias, Gonçalo e Álvaro, bem como, Gonçalo Moniz.
} 
de opinião e está como subscritor em, pelo menos ${ }^{63}$, dois dos seus documentos, em Maio $^{64}$ e Novembro ${ }^{65}$ de 958 , não voltando a apresentar-se na documentação régia de Sancho I.

Por fim, apenas o voltaremos a ver novamente em Setembro de 968, igualmente na companhia de Rodrigo Vasques e outros nobres galegos já no tempo de Ramiro III, entre os subscritores de um documento real passado ao mosteiro de Sobrado ${ }^{66}$.

$\mathrm{O}$ alinhamento destes membros da aristocracia galega que aqui escolhemos acompanhar, e aparentemente unidos numa revolta contra Ordonho III, é claro num aspecto. Apesar de implicados nessa revolta, o seu percurso documental mostra-nos que preservavam, acima de tudo, alguma prudência em relação a posicionamentos, a favor ou contra, aos vários candidatos ao trono leonês. É certo, porém, que em conjunto, se bem que com diferentes intensidades, alinharam por Sancho I.

O documento que temos vindo recorrentemente a citar mostra-nos, para além dos revoltosos, alguns dos fideles de Ordonho III que estariam na sua companhia e que, por uma questão de objectividade, não os iremos rastrear na sua totalidade e extensão, mas somente, aqueles com implicações pessoais e familiares com os condes galegos.

Ao olharmos para a massa documental que temos vindo a seguir e ao contrário do que afirma García Álvarez ${ }^{67}$, não podemos sustentar como hipótese a inclusão da estirpe de Mumadona Dias como um dos seus principais apoios nobiliárquicos. É certo que o mosteiro familiar de Guimarães irá beneficiar de uma doação régia ${ }^{68}$, no entanto, a ausência sistemática dos seus membros dessa mesma documentação, bem como, o pouco volume das respectivas prebendas, permite-nos evidenciar outras prioridades do monarca, neste caso, Leão e Santiago ${ }^{69}$.

\footnotetext{
${ }^{63}$ Encontra-se um Ueremudus a testemunhar uma doação de Ordonho IV ao mosteiro de Sobrado, sem, no entanto, nos indicar o seu patronímico. Tendo em conta a sua presença em anteriores documentos, parece-nos verosímil esta nossa suposição. Documento 106, 13 de Novembro de 958 in P. LoscerTAles de Valdeavellano, Tumbos del Monasterio de Sobrado de los Monjes..., vol. I, Tumbo Primero, págs. 125-127.

${ }^{64}$ CDCA, Documento 86, 4 de Maio de 958, págs. 125-126. Visnandus Magniti, qui est maiordomus.

${ }^{65}$ Documento do Tumbo de Lorenzana presente em: M. R. Garcia Álvarez, "Ordono IV de León...", págs. 41-43, Veremudus Magnitiz testis.

${ }_{66}$ Documento 107, 17 de Setembro de 968 in P. Loscertales de Valdeavellano, Tumbos del Monasterio de Sobrado de los Monjes, vol. I, Tumbo Primero, págs. 127-130.

${ }^{67}$ M. R. Garcia Álvarez, "La batalla de Aguioncha...", págs. 16-18.

${ }^{68}$ Não possuímos o documento da mesma, somente uma indicação indirecta presente em: Documento CCXXIII, Agosto de 1014 in Portugalia Monumenta Historica, Diplomata et Chartae, I, págs. 138-139, Et post obitum ipsius princeps Ranemirus rex ereptus est in regno filii eius ordonii principis et confirmauit ipso testamento ...eatenus et pro anima sua fecit testamentum de villa moraria ...Ipsa uilla per suis terminis et locis antiquis cum quanti homines in ea habitantes sunt ab integro.

${ }^{69}$ Os documentos onde consta o selo de Ordonho III, quer os régios, quer os privados, emanam de variadas localizações, como Leão, Santiago, Celanova, etc. Ver resenha dos mesmos: A. Isla Frez, Realezas Hispánicas del Año Mil..., págs. 34-35.
} 
De facto, nos anos que mediam o reinado de Ordonho III (951-956) imperam sobre os mesmos algum silêncio documental em relação a esta família ${ }^{70}$, impossibilitando-nos de aferir, de algum modo, o seu percurso. Esse silêncio, de certa forma, é revelador de um comportamento desapaixonado em relação à figura régia, em claro contraste, como iremos ver mais adiante, com reinados vindouros.

Em relação aos fideles presentes naquele momento gostaríamos de salientar, para além da recorrente presença dos condes de Monzón, neste caso, de Fernando Ansúrez, a figura de Paio Gonçalves ${ }^{71}$, tio e cunhado de Gonçalo Mendes. No entanto, o seu percurso assemelha-se bastante ao dos restantes membros da nobreza galega que tratámos parágrafos atrás.

Se o ramo familiar do seu irmão, Hermenegildo Gonçalves, se pautou de alguma forma pela prudência e distanciamento da figura régia, Paio Gonçalves irá ser uma figura recorrente do entorno régio, tanto de Ordonho III como de Ordonho IV e posteriormente de Sancho I.

Após um percurso iminentemente galego, Ordonho III encontra-se em Maio de 951 a conceder o seu primeiro documento em terras leonesas, neste caso, uma doação ao mosteiro de Sahagún, onde podemos encontrar entre os respectivos confirmantes, como os condes de Castela e Saldanha, a figura de Paio Gonçalves ${ }^{72}$.

Anos depois, e sem que se conheçam novas subscrições, régias ou privadas, encontramo-lo novamente na companhia do monarca, neste caso, no diploma de Maio de 955 que temos vindo a seguir ${ }^{73}$. A 5 de Maio do ano seguinte, numa doação régia que conta, para além do conde castelhano Fernão Gonçalves, observamos a última presença de Paio Gonçalves junto do monarca ${ }^{74}$.

Nesse mesmo ano, já depois da morte de Ordonho III, podemos suspeitar da sua presença no primeiro documento assinado por Sancho enquanto monarca. Sobre o mesmo, uma doação à catedral de Santiago, e sobre o séquito que o

\footnotetext{
${ }_{70}$ Para uma melhor aferição do percurso documental desta estirpe familiar, consultar: J. Mattoso, “As Famílias Condais...”, págs. 139-145.

${ }^{71}$ Podemos acompanhar o seu percurso pessoal e político em: Emilio SÁEz, "Notas al Episcopológio Minduniense del siglo X”, págs. 46-48; J. Mattoso, “As Famílias Condais...”, págs. 118-119 e V. ÁlvareZ Palenzuela, "La Nobleza del reino de León...”, págs. 208-209.

${ }_{72}$ Documento 132, 15 de Maio de 951 in J. M. Mínguez, Colección Diplomática del Monasterio de Sáhagun..., págs. 170-171, "Pelagio Gundisalviz confirmat".

73 Documento 54, 19 de Maio de 955 in J. M. Andrade Cernadas, O Tombo de Celanova..., Tomo I, págs. 86-87, Pelagius Gundisalviz ts.

74 Documento 295, 5 de Maio de 956 in Emilio SÁEz, Colección Documental del Archivo de la Catedral de León (775-1230), I (775-952), León, Centro de Estudios e Investigación San Isidoro-Archivo Histórico Diocesano de León, 1987 (Fuentes y Estudios de Historia Leonesa, núm. 41), págs. 60-63, Pelagius Gundesalbiz.
} 
acompanharia, não possuímos certezas na medida da ausência dos patronímicos de tais acompanhantes ${ }^{75}$.

Na companhia de Sancho I apenas o voltaremos a ver em Março de 95976, após ter estado presente em vários diplomas de Ordonho IV, neste caso, em Março ${ }^{77}$ e Maio de $958^{78}$.

Como se disse atrás, o percurso, ainda que explorado superficialmente, de Paio Gonçalves, permite descortinar uma certa agilidade e habilidade política para se manter, aparentemente sem demasiada controvérsia, na companhia dos vários monarcas nesta conjuntura de forte dinâmica.

Após a morte de Ordonho III em Zamora, provavelmente em Setembro de 956, ascende, relativamente de forma pacífica, à dignidade régia o seu meio-irmão Sancho. Embora essa mesma dignidade seja reconhecida a vários tempos nas diferentes geografias do reino ${ }^{79}$.

Tendo em conta os alinhamentos que relatámos parágrafos atrás, o seu reinado irá ser marcado por uma crónica instabilidade, reflectida, naturalmente, na produção documental, que, de um modo geral, será escassa ${ }^{80}$. No entanto, a mesma será sintomática para uma melhor definição desses alinhamentos em eventos futuros.

De acordo com Sampiro, e pouco tempo depois da sua entronização, ...regni sui expleto quadam arte exercitus coniuratione facta, ex Legione egressus... ${ }^{81}$. Um relato posterior elucida-nos melhor sobre este acontecimento, quanto aos

\footnotetext{
$\overline{75}$ Documento 49, 13 de Novembro de 956 in M. Lucas Álvarez, Tumbo A de la Catedral de Santiago..., págs. 126-127, Pelagius conf.

76 Documento 356, 28 de Março de 959 in J. M. Andrade Cernadas, O Tombo de Celanova..., Tomo I, págs. 512-513, Pelagius Gundesalvi.

${ }_{77}$ Neste documento apenas possuímos o primeiro nome de um certo Pelagius, no entanto, tendo em conta a totalidade dos confirmantes e testemunhas dos parcos diplomas deste monarca, verificamos que não se encontra entre os mesmos mais nenhum acompanhante de nome Pelagio, somente um Pelagius Gundisalui em documento posterior. Documento 47, 2 de Março de 958 in M. LuCAs Álvarez, Tumbo A de la Catedral de Santiago..., pág. 123, Pelagius.

78 Documento 48, 21 de Maio de 958 in M. Lucas Álvarez, Tumbo A de la Catedral de Santiago..., págs. 124-125, Pelagius Gundisalui ts.

${ }^{79}$ Em Novembro de 956, logo após a morte de Ordonho III, Sancho era reconhecido como rei na Galiza, ...Sancius, nutu diuino in regno fultus...; em Castela seria a 14 de Janeiro do ano seguinte que o reconheceriam como rei, ...regnante rex Sancio in Legione, Documento CCX, 14 de janeiro de 957 in Luciano Serrano (ed.), Becerro Gótico de Cardena..., págs. 224-225 e na zona de Leão de forma intermitente. Em Sahagún a 13 de Fevereiro desse mesmo ano de 957, ...Sub Sanzoni rex in Legione, Documento 154, 13 de Fevereiro de 957 in José Maria Mínguez, Colección Diplomática del Monasterio de Sáhagun (siglos IX y X), pág. 193 e em Leão a 12 de Janeiro de 958, ...Regnante rege domno Sango in Letion, Documento 305, 12 de Janeiro de 958 in E. SÁEz e C. SÁEz, Colección Documental del Archivo de la Catedral de León..., págs. 76-77.

${ }^{80}$ A. Isla Frez, Realezas Hispánicas del Ano Mil..., pág. 32.

${ }^{81}$ Historia Silense, edición preparada por Francisco Santos Coco, pág. 54.
} 
participantes, ...tunc illis diebus cogitans comites gallecos necnon et magnati palatii eicere Sancionem de sede sua Legione... ${ }^{82}$. Adiante, ficamos a saber o objecto imediato destas manobras, ...et dare tronum glorie regni ad Ordonium prolis Adefonsi... ${ }^{83}$, contanto com ajuda castelhana, ...consilio inito cum Fredinando Burgensium comite... ${ }^{84}$.

Não nos iremos deter objectivamente sobre estes acontecimentos nem na respectiva conjuntura, no entanto, gostaríamos de fazer uma pequena nota sobre uma aparente contradição, e ainda não totalmente esclarecida.

Olhando para a documentação conhecida de Ordonho IV $^{85}$ ela reporta-se quase em exclusivo a doações a Santiago e ao respectivo bispo e, por outro lado, é em terras castelhanas, e não na Galiza, que o seu imperium será primeiramente reconhecido $^{86}$ e mais tempo respeitado ${ }^{87}$.

$\mathrm{Na}$ ausência de fontes narrativas que nos elucidem melhor, será nessa mesma documentação que podemos observar alguns desses comites gallecos que o apoiaram, nomeadamente, e entre outros, a família do bispo de Santiago, Sisnando Mendes $^{88}$.

Ao contrário de alguns autores, entre os quais, Luís Gonzaga de Azevedo, Paulo Merêa e José Mattoso ${ }^{89}$, e apesar desses mesmos comites serem seus familiares, de sangue e de afinidade, não vislumbramos na documentação um envolvimento directo nem um apoio tácito de Gonçalo Mendes, nem da sua estirpe familiar, a Ordonho IV.

Assim, entre alguns nomes de difícil identificação, encontramos recorrentemente Rodrigo Mendes (Rudericus Menendici) ${ }^{90}$, irmão do bispo Sisnando

\footnotetext{
${ }_{82}$ Documento 265,1 de Outubro de 982 in J. M. Andrade Cernadas, O Tombo de Celanova..., Tomo I, pág. 380 .

83 Documento 265, 1 de Outubro de 982 in J. M. Andrade Cernadas, O Tombo de Celanova..., Tomo I, pág. 380 .

${ }^{84}$ Historia Silense, edición preparada por Francisco Santos Coco, pág. 55.

${ }^{85}$ Baseamo-nos em, M. Lucas Álvarez, “Cancillerías Reales Astur-Leonesas (718-1072)...”, págs. 340341 e M. R. García Álvarez, “Ordono IV de León...”, págs. 35-46.

${ }^{86}$ Apesar de alguma incerteza, observamos a 1 de Junho de 957: ... regnante rex Ordonio in Legione, et in Castella comite Fredinando Gundissalbiz, Documento CCCXLIV, 1 de Junho de 957 in Luciano SERRANo (ed.), Becerro Gótico de Cardena..., págs. 351-352.

87 Documento LXIV, 3 de Fevereiro de 961 in L. Serrano (ed.), Becerro Gótico de Cardena..., págs. 77-78, ...regnante rex Ordonio in Obeto, et comite Fernando Gundissalbiz in Castella.

${ }^{88}$ Sobre a sua figura e a sua acção, a qual não iremos abordar neste artigo, ver: Manuel CARRIEDo TEJEDO, "Sisnando II de Santiago (951-968): Totius orbis antistes", Compostellanum, vol. LVIII, núms. 3-4 (2013), págs. 543-606.

${ }^{89}$ L. G. de Azevedo, História de Portugal, volume segundo, págs. 104-105; Paulo MerÊA, De "Portucale" (civitas) ao Portugal de D. Henrique, pág. 14 e J. Mattoso, "Portugal no reino Astur-Leonês", in História de Portugal, vol. 1, Lisboa, Círculo de Leitores, 1992, pág. 537.

90 Documento 46, 2 de Março de 958 in M. Lucas Álvarez, Tumbo A de la Catedral de Santiago..., págs. 121-122; Documento 47, 2 de Março de 958 in M. Lucas Álvarez, Tumbo A de la Catedral de
} 
e, embora com presença reduzida, Lucídio Alvites (Lucidus) ${ }^{91}$, seu cunhado e primo direito de Gonçalo Mendes e Paio Gonçalves (Pelagius Gundisalui) ${ }^{92}$, tio e sogro de Gonçalo Mendes. E fica igualmente claro a atenção que Ordonho IV irá ter pela sede Compostelana, pois como já se disse, a maioria dos seus diplomas dizem-lhe respeito. Em contraste com a segunda metade do reinado de Sancho I (959-966).

Com o seu regresso a solo cristão, e eventualmente como forma de agradecimento pela mudança de apoio ${ }^{93}$, e até pela sua importância na política galega, Sancho I dirige-se primeiramente a Celanova onde procede a uma doação de uma mina de ferro ao mosteiro e respectivo abade, S. Rosendo ${ }^{94}$, concentrando posteriormente a sua acção na região leonesa, especialmente em redor de Sahagún.

Nestas linhas atrás e antes de avançarmos para mais uma nova etapa desta nossa análise, o assassinato régio de Sancho I, importa reter algumas ideias. O comportamento e as respectivas acções dos vários nobres, laicos e religiosos, aqui falados, caracteriza-se pela prudência e, tendo em conta os laços inter-dependentes entre as principais figuras da aristocracia e os vários protagonistas régios, é com bastante razoabilidade que os desavindos membros destas linhagens regressem à companhia dos monarcas, como se constata pelo percurso, e a título de exemplo, de S. Rosendo e de Sisnando de Iria, que encontrando-se entre os proceres de Ordonho IV, posteriormente já integrariam, em lugar de destaque, o séquito de Sancho I.

Relativamente a partidos, quer Rodrigo Vasques, quer Gonçalo Moniz e Gonçalo Mendes, são igualmente exemplo dessa prudência, não se notando nas sua acções, até agora, um claro e evidente comprometimento com a acção/oposição ao monarca, embora seja evidente que Gonçalo Mendes não se incluiria amiúde na companhia de Sancho I.

As ausências da documentação régia parecem-me significativas, pois haveria certamente um ritual de nova submissão a realizar o que, aparentemente, nem

\footnotetext{
Santiago..., pág. 123; M. R. Garcia Álvarez, “Ordono IV de León...”, documento 6 de 11 de Novembro de 958 e Documento 106, 13 de Novembro de 958 in P. Loscertales de Valdeavellano, Tumbos del Monasterio de Sobrado de los Monjes..., vol. I, Tumbo Primero, págs. 125-127.

${ }^{91}$ Documento 46, 2 de Março de 958 in M. Lucas Álvarez, Tumbo A de la Catedral de Santiago..., págs. 212-122; Documento 47, 2 de Março de 958 in M. Lucas Álvarez, Tumbo A de la Catedral de Santiago..., pág. 123.

92 Documento 48, 21 de Maio de 958 in M. Lucas Álvarez, Tumbo A de la Catedral de Santiago..., pág. 124.

${ }_{93}$ S. Rosendo Rudesindus episcopus consta nos dois primeiros documentos de Ordonho IV. Documento 46, 2 de Março de 958 in M. Lucas Álvarez, Tumbo A de la Catedral de Santiago..., págs. 212-122; Documento 47, 2 de Março de 958 in M. Lucas Álvarez, Tumbo A de la Catedral de Santiago..., pág. 123. 94 Documento 356, 28 de Março de 959 in J. M. Andrade Cernadas, O Tombo de Celanova..., Tomo I, págs. 512-513.
} 
todos estariam confortáveis para o fazer. A exclusão dos prelados da região a Sul do Minho na posterior documentação de Sancho I parece-me pertinente à luz dos acontecimentos que irão rodear a morte do monarca aquando do seu regresso a terras leonesas após uma digressão pelo condado de Coimbra.

\section{UM ASSASSINATO RÉGIO}

De um modo geral o reinado de Sancho I é marcado pela conflitualidade, acentuando-se particularmente após a sua vinda do exílio. Esta última etapa irá ser novamente marcado pela instabilidade vinda da região galega, sem dúvida, ainda reminiscências da divisão dos vários membros da aristocracia sobre a figura régia e, neste caso, e na nossa opinião, relacionada igualmente com a tentativa de afirmar essa mesma figura através da iusso regia em questões fiscais.

Sancho, acompanhado de um exército, empreende uma viagem a essas terras ocidentais para debelar certos focos insurreccionais e garantir, deste modo, a submissão dos protagonistas, ...egressus rex Sancius Legione venit Galleciam, et edomuit eam usque ad flumen Dorii. Quo audito Gundissalvus qui dux erat ultra flumen illud, congregato magno exercitu venit usque ripam ipsius fluminis; deinde missis nuntiis et coniuratione facta, ut exsolveret tributum ex ipsa terra quam tenebat... ${ }^{95}$.

Sobre o enquadramento geral desta instabilidade, que certamente motivou a vinda do rei às paragens ocidentais do reino, um documento do mosteiro de Abelio, presente no cartório do mosteiro de Sobrado, e datado de Março de 960, elucidanos melhor, Cumque possideret diabolus corda cunctorum infelicium ut spreuerent et abnegarent regem catholicum et odirent leges eius et contennerent iussa eius atque tributa ... ${ }^{96}$, levando a comunidade religiosa a procurar protecção junto de S. Rosendo e do mosteiro de Celanova, ...nos inde in longinquis partibus ubi alia nostra erat hereditas, ubi aliquantulum sedata erat malitia talium peruersorum infausta rapacitas ${ }^{97}$. No entanto, e em relação especificamente a terras hoje portuguesas, concretamente à região a Sul do Douro, temos mais exemplos desse clima propício à insegurança.

De acordo com os últimos dados extraídos de recentes escavações arqueológicas em Trancoso (Guarda), observa-se nas camadas datadas deste período

\footnotetext{
${ }_{95}$ Historia Silense, edición preparada por Francisco Santos Coco, pág. 56.

96 Documento 122, 3 de Março de 960 in P. Loscertales de Valdeavellano, Tumbos del Monasterio de Sobrado de los Monjes..., vol. I, Tumbo Primero, págs. 151-152.

97 Documento 122, 3 de Março de 960 in P. Loscertales de Valdeavellano, Tumbos del Monasterio de Sobrado de los Monjes..., vol. I, Tumbo Primero, págs. 151-152.
} 
alto-medieval vários níveis de incêndios e de intensa actividade militar, como restos abundantes de carvões, pontas de seta e lança, entre outros ${ }^{98}$.

Novo exemplo deste ambiente de instabilidade encontra-se igualmente patente na zona de Gouveia (Guarda), concretamente numa zona conhecida por Penedo dos Mouros. As últimas informações disponíveis dizem-nos que o mesmo foi abandonado após um incêndio na segunda metade do séc. $\mathrm{X}^{99}$. Outros povoados no Alto Mondego, de idêntica tipologia, tiverem semelhante fim possivelmente dentro do mesmo contexto ${ }^{100}$.

Será, portanto, dentro deste cenário que Sancho, após aplacar o descontentamento nas terras a Norte do Douro, se entrevista com Gonçalo Mendes ${ }^{101}$, estando este último acompanhado por um grande exército, em local não referenciado, mas nas imediações desse rio, ...Quo audito Gundissalvus qui dux erat ultra flumen illud, congregato magno exercitu venit usque ripam ipsius fluminis ${ }^{102} . \mathrm{Na}$ sequência desse encontro, e tomando as palavras de Sampiro, ...callide adversus regem cogitans, veneni pocula illi in pomo duxit. Quod dum gustasset, sensit cor suum immutatum; silenter musitans, festinus cepit remeare ad Legionem. In ipso itinere die tertio vitam finivit ${ }^{103}$.

Sobre esta questão, e apesar da simplicidade do relato, a mesma não nos oferece muitas dúvidas sobre quem recai o ónus pelo assassinato de Sancho I, e não conseguimos vislumbrar nas várias fontes disponíveis sustento para a cumplicidade de Gonçalo Moniz, conde de Coimbra, nesta matéria. Aliás, nos principais estudos ${ }^{104}$

\footnotetext{
98 Maria do Céu Ferreira e João Carlos Lobão, “Arqueologia no castelo de Trancoso: novos dados para o estudo da fortificação", in Fortificações e Território na Península Ibérica e no Magreb (Séculos VI a XVI), vol. II, Lisboa, Edições Colibri-Campo Arqueológico de Mértola, 2013, pág. 766.

E é preciso termos presente que Trancoso, bem como outras localidades do interior da actual região da Beira, estariam na posse da família de Gonçalo Mendes.

${ }^{99}$ Catarina Tente, "Viver em autarcia. A organização do território do alto Mondego (Portugal) entre os séculos V a X", in Tiempos Oscuros. territorios y Sociedad en el centro de la Península Ibérica (siglos VII-X), Sílex ediciones-Universidad de Salamanca, 2009, págs. 145-147.

${ }^{100}$ C. TENTE, "Viver em autarcia. A organização...", págs. 148-153.

${ }^{101}$ A principal e única fonte a salientar este episódio refere-se ao seu protagonista como Gundissalvus qui dux erat ultra flúmen..., assumindo alguns autores, nomeadamente, e entre outros, José Mattoso, que Sampiro se estaria a referir ao conde de Coimbra, Gonçalo Moniz. O caminho que irei percorrer e propor, irá em sentido contrário, como se verá.

${ }^{102}$ Historia Silense, edição preparada por Francisco Santos Coco, pág. 56.

${ }^{103}$ Historia Silense, edição preparada por Francisco Santos Coco, pág. 56.

${ }^{104}$ Entre outros estudos e publicações, salientamos somente: Justo PÉrEZ DE Urbel, Sampiro. Su Cronica y la Monarquía Leonesa en el siglo X, Madrid, Consejo Superior de Investigaciones Científicas-Escuela de Estudios Medievales, 1952 (Estudios, vol. XXVI), pág. 427; J. RodríGuEz, "Gonzalo Munoz...", pág. 117; Justiniano Rodríguez, "La Monarquía Leonesa. De García I a Vermudo III (910-1037)", in El Reino de León en la Alta Edad Media, vol. III, León, Centro de Estudios e Investigación "San Isidoro", 1995 (Fuentes y estudios de historia leonesa), págs. 319-320; J. Matтoso, "As Famílias Condais...", pág. 122; J. Mattoso, "Portugal no reino Astur-Leonês...”, pág. 538 e L. G. de Azevedo, História de Portugal, volume segundo, págs. 107-108.
} 
que indirectamente abordam o assassinato régio, o mesmo irá ter lugar ainda em terras próximas de Coimbra, no entanto, pensamos nós, esta tese caracteriza-se pela omissão de elementos que a poderiam solidificar.

Esta doação régia ao mosteiro de Lorvão ${ }^{105}$ proporciona-nos alguns indicadores interessantes para a questão em si, pois, e ao contrário de uma anterior presença em Lorvão $^{106}$, nesta passagem destacam-se como seus acompanhantes o seu armiger Gonçalo Bermudes e o seu maiordomo Inigo Aznárez, pautando pela ausência qualquer membro da aristocracia galega, exceptuando naturalmente o seu anfitrião Gonçalo Moniz. Ou seja, o rei e respectivo séquito, por uma qualquer razão não inteiramente especificada ${ }^{107}$, deslocam-se a terras próximas de Coimbra efectuando ao abade Primo de Lorvão uma doação de algumas propriedades, transmitindonos, de certa forma, um ambiente natural da acção régia.

Com base nas fontes narrativas, e ao contrário do que correntemente se tem avançado, poderá ter sido no seu regresso às margens do Douro que Sancho se entrevista com Gonçalo Mendes, que, para além da sua implantação regional se localizar precisamente nas imediações desse rio, tanto a Norte, como a Sul, tem a necessidade de levar consigo para a dita entrevista o seu exército (magno exercitu).

Tanto Sampiro, ...egressus rex Sancius Legione venit Galleciam, et edomuit eam usque ad flumen Dorii ${ }^{108}$, como, por exemplo, Rodrigo Jiménez de Rada, Et hac legatione pendente, Gallaeci discordes inter se praedas et injurias exercebant. Sed Rex adveniens, insolentes domuit et iniuriosos coegit usque ad Dorium, qui dividit Gallaeciam et Lusitaniam ${ }^{109}$, são taxativos em balizarem geograficamente essa revolta galega, ou seja, em terras a Norte do Douro, levando-nos a pensar que a Sul não haveriam membros da aristocracia a encabeçarem esses focos de contestação ali existentes.

O percurso futuro de Gonçalo Moniz, e tendo em conta que os membros do séquito de Sancho I sabiam quem tinha sido o responsável pelo regicídio ${ }^{110}$,

\footnotetext{
${ }^{105}$ Documento XCII, 15 de Novembro de 966 in Portugalia Monumenta Historica, Diplomata et Chartae, $I$, pág. 58 .

${ }^{106}$ Documento CVII, Março de 966 in Portugalia Monumenta Historica, Diplomata et Chartae, I, pág. 68. Nesta sua passagem por terras a Sul do Douro e tal como já referimos anteriormente, Sancho encontra-se a confirmar uma doação de Munia Dias ao mosteiro de Lorvão, onde se encontrava na companhia de vários elementos do clã de Gonçalo Mendes, ainda que não da sua estirpe directa. Podemos encontrar, entre outros nomes, Alvito Lucides, marido da referida Munia Dias e Rodrigo Tedones, casado com Leodegúndia Dias, irmã de Munia. São Rosendo e Gonçalo Moniz também se encontravam presentes.

${ }^{107}$ Será bem possível que esta presença de Sancho e do seu exército se enquadre na supressão do clima de insegurança local que falámos linhas atrás, e que, pela sua eventual irrelevância política, não se encontrem mencionadas nas fontes narrativas que temos vindo a seguir.

${ }^{108}$ Historia Silense, edição preparada por Francisco Santos Coco, pág. 56.

${ }^{109}$ Citação presente em: J. Rodríguez, "La Monarquía Leonesa...”, pág. 319, nota 569.

${ }^{110}$ Sampiro fala-nos de um Gundissalvus, que cremos ser Gonçalo Mendes, e essa informação provavelmente lhe foi transmitida por interposta pessoa, necessariamente em contacto directo ou indirecto com um membro do séquito do rei envenenado.
} 
aparenta normalidade, ao contrário do que observamos na vida política de Gonçalo Mendes.

A ausência de volume documental, como vimos anteriormente, não nos permite traçar com rigor todo o percurso pessoal e político deste conde portucalense, em particular, neste período, no entanto, o mesmo revela-se iminentemente pessoal, deslocado da companhia régia e ausente do espaço geográfico comum.

Nos anos posteriores ao regicídio apenas nos chegam dois diplomas onde o podemos encontrar, ambos particulares. Um primeiro ${ }^{111}$, onde a sua mãe Mumadona estipula a utilização e os fins do recém-construído castelo de Guimarães e um segundo ${ }^{112}$, uma doação ao cenóbio familiar de algumas propriedades. Após esta data apenas o voltamos a localizar já no período de afirmação de Bermudo II, filho de Ordonho III, num diploma do mosteiro de Lorvão em $981^{113}$.

Ou seja, estas pequenas notas ilustram-nos uma movimentação de âmbito restrito, mais localizada no seu entorno geográfico, apesar do seu património se dispersar por outras zonas mais abrangentes. Veremos mais adiante que Gonçalo Mendes apenas será protagonista político de relevo aquando da afirmação de Bermudo II, em clara confrontação com o filho de Sancho I, o então rei Ramiro III.

Em contraste com este apartamento de Gonçalo Mendes, vamos encontrar Gonçalo Moniz a desempenhar as suas funções de curador do seu património familiar e a dirimir contendas nas várias geografias com ele relacionadas, de certo modo, exercendo a sua potestas sem qualquer constrangimento.

Assim, logo em Abril de $967^{114}$ iremos encontrar o conde de Coimbra presente como testemunha num documento de filiação localizado no cartório da catedral de Leão, atestando, deste modo, o prestígio que Gonçalo Moniz e respectiva família detinham nessa região.

Igualmente em Abril, mas já de 970, o nome de Gonçalo Moniz será mencionado num documento onde se encontram presentes, para além de Ramiro III e da sua tia a regente Elvira, vários outros dignatários que estariam presentes na companhia de Sancho aquando do seu envenenamento ${ }^{115}$. O documento ${ }^{116}$ relata-nos

\footnotetext{
${ }^{111}$ Documento XCVII, Novembro de 968 in Portugalia Monumenta Historica, Diplomata et Chartae, I, pág. 61.

${ }^{112}$ Documento XCIX, Dezembro de 968 in Portugalia Monumenta Historica, Diplomata et Chartae, I, págs. 62-63.

${ }^{113}$ Documento CXXXII, Dezembro de 981 in Portugalia Monumenta Historica, Diplomata et Chartae, I, págs. 81-82.

${ }^{114}$ Documento 402, 26 de Abril de 967 in E. SÁez e C. SÁez, Colección Documental del Archivo de la Catedral de León..., págs. 187-188.

${ }^{115}$ Como Fernando Bermudes (Fredenando Veremudiz), Nepociano Dias (Nepotianus Didaci) e Fernando Rodrigo (Fredenandus Ruderici).
} 
a doação de umas propriedades ao mosteiro de Sahagún, e nele não constatamos nenhuma especial referência a qualquer particularismo ou adjectivação (canii por exemplo) a Gonçalo Moniz.

Posteriormente, num documento régio datado de Junho de $977^{117}$ e, entre várias personalidades da aristocracia laica e eclesiástica que apensam a sua assinatura ao mesmo, observamos novamente Gonçalo Moniz. Ou seja, encontrando-se na companhia do filho de Sancho I, tornando tal facto pouco verosímil se se tratasse do regicida, até pela ausência sistemática de qualquer referência aquando da menção do seu nome ou património fundiário nos vários documentos que chamamos à colação nos parágrafos anteriores.

\section{A CONSOLIDAÇÃo ARISTOCRÁTICA. O REINAdo DE RAMIRO III}

Uma vez falecido Sancho I a caminho de Leão, sucede-lhe no trono o seu filho Ramiro (966-982), o qual, por ter somente cinco anos, verá a sua tia Elvira Ramires assumir a regência, Sancio defuncto, filius eius Ranimirus habens a nativitate annos quinque suscepit regnum patris sui, continens se cum consilio amite sue domne Geluira... ${ }^{118}$.

Ainda de acordo com Sampiro o seu reinado virá a ser marcado por alguns focos de confrontação, onde sobressai, mais uma vez, a zona galega ou os finibus Gallecie, Anno secundo regni sui C classes Normannorum ...ingresse sunt urbes Gallecie, et strages multas facientes in giro sancti Iacobi... ${ }^{119}$. Posteriormente, já na parte final do seu reinado, Rex vero Ranimirus, cum esset in pueritia et modica scientia, cepit comites Gallecie factis ac verbis contristari. Ipsi quidem comites talia ferentes, callide adversus eum cogitaverunt, et regem alium nomine Veremudum super se exerunt, qui fuit ordinatus in sede sancti Iacobi apostoli... ${ }^{120}$.

As palavras do cronista ilustram-nos um ambiente instável onde a figura régia não sai propriamente favorecida, antes pelo contrário. Será, então, em conjugação com as várias fontes documentais disponíveis que iremos olhar para o intrincado contexto desse ambiente, não necessariamente e de forma uniforme, de contestação régia, mas sim, e igualmente, de defesa dos particularismos dos diversos

\footnotetext{
${ }^{116}$ Documento 255, 4 de Abril de 970 in J. M. MínguEZ, Colección Diplomática del Monasterio de Sáhagun (siglos IX y X) ..., págs. 300-302, ... Rex vero dominus et frater meus Sanctius omnia summerat dandi et tollendi; dedit ipsas villas Gundisalvo Nunniz que nunc usque iuris obtinuit.

${ }^{117}$ Documento 290, 16 de Junho de 977 in J. M. Mínguez, Colección Diplomática del Monasterio de Sáhagun (siglos $I X$ y X) ..., págs. 349-351.

Temos de olhar com cautela para o teor do documento pois, de acordo com o editor da referida colecção documental, o mesmo reveste-se de algumas imprecisões. Ver nota na pág. 351.

${ }^{118}$ Historia Silense, edição preparada por Francisco Santos Coco, pág. 56.

${ }^{119}$ Historia Silense, edição preparada por Francisco Santos Coco, págs. 56-57.

${ }^{120}$ Historia Silense, edição preparada por Francisco Santos Coco, pág. 57.
} 
intervenientes, levando, deste modo, a uma insustentável posição de Ramiro III enquanto monarca.

Como se disse no parágrafo atrás, a região compostelana irá sofrer um novo ${ }^{121}$ ataque predatório normando nos inícios de 968, levando à reacção do bispo de Iria, Sisnando, e no decurso da mesma virá a falecer, ...episcopum loci illius gladio peremerunt... ${ }^{122}$.

Após este desaire militar, e mais uma vez de acordo com Sampiro, os normandos chefiados por Gunderedo, efectuam pilhagens várias por todo o território galego, aparentemente sem oposição e somente derrotados um ano depois do seu desembarque por um conde de nome Guillermo Sánchez (Guillelmus Sancionis), que na opinião de Justiniano Rodríguez, homónimo de um nobre gascão, cunhado do rei de Navarra Sancho Garcés II ${ }^{123}$.

Este episódio é revelador de uma eventual ausência de unidade para debelar semelhante ameaça, onde, cada magnate procura agir segundo a sua percepção imediata, como parece ter sido o caso da família de Mumadona Dias, em terras mais a Sul. Podemos relacionar esta actividade predatória normanda com a construção coeva do castelo de Guimarães, Post non multo uero temporis quod hunc serie testamenti in conspectu multorum est confirmatum persecutio gentilium irruit in huius nostre religionis suburbium et ante illorum metum laborauimus castellum quod uocitant sanctum mames in locum predictum alpe latito... ${ }^{124}$.

Outro dado significativo é a presença em Leão, em Setembro de $968^{125}$, após a derrota e morte de Sisnando de Iria, de um nutrido conjunto de nobres leoneses e galegos que assistem à doação régia de algumas circunscrições administrativas ao mosteiro de Sobrado, onde podemos encontrar, entre outros, Froila Vélaz (Froila Uegilat), Fernando Bermudes (Fredenandus Ueremudiz), Nepociano Dias (Nepotianus Didaci), Bermudo Magnítiz (Ueremudus Magnitiz), Mendo Gonçalves (Menendus Gundisaluiz), Rodrigo Vasques (Rudericus Uelasquiz) e Sueiro Gundemariz (Suarius Gundemariz).

\footnotetext{
${ }^{121}$ Face a este clima de instabilidade marítima, o bispo Sisnando solicita autorização a Sancho I para erigir muralhas e demais protecções para a defesa da envolvente do mosteiro, ...Sisnando... cum rege sancio accepto consilio propter hostilitatis diram seuamque incursionem normannorum ...circumquaque eundem Locum Sanctum menium, turriumque munitione ac profundis uallorum fossis aqua circumfusa.... Citação do Chronicon Iriense extraída de M. CARRIEDo TEJEdo, "Sisnando II de Santiago...”, pág. 583.

${ }^{122}$ Historia Silense, edição preparada por Francisco Santos Coco, pág. 57.

${ }^{123}$ J. RodRíGuEz, "La Monarquía Leonesa...”, pág. 333.

Para mais informações e detalhe na análise cronística desta campanha ver: Hélio PIREs, Incursões Nórdicas no Ocidente Ibérico (844-1147): Fontes, História e Vestígios, Dissertação de Doutoramento policopiada, 2012, págs. 136-148.

${ }^{124}$ Documento XCVII, Dezembro de 968 in Portugalia Monumenta Historica, Diplomata et Chartae, I, pág. 61.

${ }^{125}$ Documento 107, 17 de Setembro de 968 in P. Loscertales de Valdeavellano, Tumbos del Monasterio de Sobrado de los Monjes..., vol. I, Tumbo Primero, págs. 127-130.
} 
Como pequeno apontamento sobre este documento e respectivo significado, assinalamos a presença deste conjunto de membros da aristocracia galega na companhia de Ramiro III, que, pensamos nós, e tendo em conta o contexto bélico, procuravam assistência do monarca e da regente para debelarem esse foco de instabilidade que, entretanto, se tinha instalado nas suas terras. A ausência de resposta do monarca e, entre múltiplas outras razões, levarão certamente ao afastamento de parte significativa desta nobreza em anos vindouros, com claro reflexo na promoção de Bermudo II à dignidade régia.

Um dado significativo a ilustrar a fragilidade do monarca, e subsequentemente da regente Elvira, é o facto de, e num sinal de crescente fortalecimento da aristocracia territorial, vários membros se representarem a si próprios junto do califa, ilustrando um ambiente de clara independência face à monarquia e um reconhecimento do papel de Córdoba na sustentação dessa mesma independência.

As fontes cristãs são omissas em relação a essas actividades diplomáticas, dando-nos Sampiro somente algumas linhas indirectas sobre o resultado das mesmas, Habuit pacem cum Sarracenis ... ${ }^{126}$. No entanto, de acordo com fontes muçulmanas ${ }^{127}$, seriam de certa forma intensas as movimentações em direcção à corte de al-Hakam II, com múltiplos dignatários representando vários membros da aristocracia astur-leonesa ${ }^{128}$.

Retomando o fio condutor que nos interessa, sabemos que Gonçalo Moniz (Gundisalb ibn Munio), estando em Astorga, expediu uma carta para o califa em Julho de 971, alertando-o que piratas normandos teriam entrado no rio Douro atacando uma povoação actualmente não identificada (Santaver) nos inícios desse mesmo mês.

Esta missiva do conde de Coimbra é deveras curiosa, até pela urgência com que a mesma fora redigida e expedida. De acordo com o editor dos Anais Palatinos ${ }^{129}$, esta carta leva o selo de 9 de Julho de 971, sendo que a mesma, como referido, chegou a Córdoba a 22 de Julho. Para além de outras considerações possíveis de se fazer ${ }^{130}$, esta urgência em informar al-Hakam revela uma certa percepção da inoperância régia em lidar com determinados aspectos da governação, nomeada-

\footnotetext{
${ }^{126}$ Historia Silense, edição preparada por Francisco Santos Coco, pág. 56.

${ }^{127}$ Nomeadamente os Anales palatinos del Califa de Córdoba al-Hakam, por isa Ibn Ahmad al-Razi, tradução de Emilio García Gómez, Madrid, 1967.

${ }^{128}$ Consideremos aqui igualmente a regente Elvira que em duas ocasiões, pelo menos, envia emissários, no entanto, a avaliar pelas fontes, em nada se distinguem das demais embaixadas. Assim a 12 de Agosto de 971, a 30 de Setembro do mesmo ano e a 17 de Novembro de 973, o califa recebe dignatários da tia de Ramiro III.

Para melhor enquadramento, J. RodRíGuEz, “La Monarquía Leonesa...”, págs. 334-335.

${ }^{129}$ Opinião expressa localizada em: H. PIREs, Incursões Nórdicas ..., pág. 152.

${ }^{130}$ H. PIREs, Incursões Nórdicas..., págs. 148-151.
} 
mente, em agregar em si uma força militar capaz de fazer frente às várias ameaças latentes e concretas. Como foi o caso das incursões normandas na Galiza.

Sabemos, no entanto, que aquando da recepção da carta de Gonçalo Moniz encontrava-se igualmente presente o general Gálib que, face a essas mesmas notícias, apronta-se, num elaborado ceremonial marcial ${ }^{131}$, para empreender uma aceifa contra os majús ${ }^{132}$.

Outro magnate galego a levar a cabo uma política autónoma, sem que a definição de "política" acarrete, neste caso, um enquadramento geo-estratégio, mas somente, pensamos nós, de prestígio e de mero interesse pessoal, seria Rodrigo Vasques.

A sua embaixada seria encabeçada pela sua mãe, Dona Trodilde, que chegaria a Córdoba, em conjunto com outros dignatários, em Setembro de 973, The mother of Count Ludherik Ibn Beláshk went also to the court of Al-hakem. This Ludherik was a powerful chieftain, whose states bordered upon Galicia ... granted the peace she requested on behalf of her son, gave her a large sum of money to be distributed among her attendants, besides a rich present for herself ${ }^{133}$.

Este conjunto de movimentações diplomáticas é um tanto anacrónico, pois podemos encontrar Gonçalo Moniz a informar o califa cordobês tendo em vista uma posterior acção deste último contra os povos do Norte europeu; e encontrar Rodrigo Vasques preocupado em garantir para as suas propriedades uma certa imunidade face às depredações navais levadas a efeito pelos muçulmanos ${ }^{134}$. Será, naturalmente, reflexo próprio de diversas e variadas agendas políticas, nem sempre, ou raramente, concordantes entre as famílias mais influentes do reino astur-leonês, pois, para além dos condes galegos e da regente Elvira, em nome do jovem rei Ramiro, encontramos igualmente emissários de Castela, Saldanha, Salamanca, etc., bem como, de outras geografias, Barcelona e Pamplona, por exemplo, a procurar entrevistarem-se com o califa.

Outro marco característico desta conjuntura são os conflitos aristocráticos entre os seus membros, desembocando, por vezes, em episódios bélicos.

\footnotetext{
${ }^{131}$ Passagem do ceremonial extraída dos Anales Palatinos e presente em: Virgilio MartínEz e Antonio Torremocha, Almanzor y su época. Al-Andalus en la segunda mitad del siglo X, Málaga, Editorial Sarriá, 2001, pág. 118.

${ }^{132}$ Mohamed MeouaK, "La Biographie de Galib, haut functionnaire andalou de l'époque califale: carrière politique et titres honorifiques”, Al-Qantara, vol. XI, I (1990), págs. 99-100.

${ }^{133}$ Al-Makkarí, The History of the Mohammedan Dynasties in Spain, vol. II, edição de Pascual de Gayangos, Londres, 1843, pág. 166.

${ }^{134}$ Em 965 ...ordenó al-Hakam construir naves de guerra en todas las costas. Ese mismo año (hégira 354) hizo una expedición contra el Norte; realizó una grande matanza y regresó con diez mil prisioneros. Citação de Una descripción anónima de al-Ándalus, vol. II, pág. 181, tradução de Luis Molina, presente em: M. Carriedo TeJedo, "Sisnando II de Santiago...”, pág. 582.
} 
Nas terras da fachada atlântica do reino e por aquilo que as fontes, nomeadamente documentais, nos mostram a envergadura dessas confrontações não foram negligenciáveis, pelo capital político e social dos intervenientes, e pela disponibilidade de meios neles investidos, principalmente humanos.

Numa data não inteiramente especificada ${ }^{135}$, e cujos motivos apenas nos permitem especular, os condes galegos, Gonçalo Mendes e Rodrigo Vasques, irão dar testemunho das suas diferenças numa disputa armada na região de Orense, em Aguioncha, Defuncto autem ipso Santio principe accepit regnum eius germana sua domna Gilvira et perunctus est in regno filius ipsius Santionis nomine Ranemirus ...Tunc in illis diebus excitaverunt gallecos inter se sedicionem comites duo unum Rudericum Velasconiz, et alterum Gundisalvum Menendiz qui multa inter se per internuntios recalcitrantes et adversus invicem verba tyrannidem inusitantes ... Consilio autem initio, ipse Gundisalvus cum suis satellitibus et cum multis qui cum ipso Ruderico erant et ei verba mentiosa dabant, inito certamine in locum quod dicunt Aquiluntras ... ${ }^{136}$.

Não nos querendo alongar sobre este momento bélico, até porque o mesmo já fora tratado nas suas linhas gerais ${ }^{137}$, temos somente a assinalar que a visão de Rubén García Álvarez sobre o mesmo, em que tudo se resume às disputas entre facções dos vários protagonistas ao trono de Leão, parece-nos demasiada redutora. De acordo com o documento, existem vários protagonistas, laicos e eclesiásticos, envolvidos na resolução do problema central em relação à posse de uma propriedade e respectivo cenóbio, ecclesia sancta Columba (com as respectivas rendas que o mesmo certamente proporcionaria ao seu proprietário), e cuja intervenção irá ser modulada pela envolvência política e social onde esses mesmos protagonistas se irão mover.

Este acontecimento, mas sobretudo o documento onde o mesmo é relatado, é um dos momentos marcantes das vicissitudes do reino leonês, pois ao abarcar praticamente a totalidade do período histórico que nos traz a estas linhas, em virtude da extensa e complexa relação desta Casa monástica com diversos protagonistas detentores de peso político, como as famílias de Rodrigo Vasques e de Mumadona Dias, o mesmo revela-nos pormenores únicos da governação e da respectiva conjuntura que passaram despercebidos nas restantes fontes

\footnotetext{
${ }^{135}$ José-Luis Martín, "Pelayo Rodríguez, Obispo de Santiago (977-985)", Anuario de Estudios Medievales, vol. 2 (1965), pág. 473, avança como data provável entre 966 e 967, enquanto M. R. GARCIA ÁlvarEz, "La batalla de Aguioncha...", pág. 29, remete-nos para entre 970-974.

${ }^{136}$ Documento 265, 1 de Outubro de 982 in J. M. Andrade Cernadas, O Tombo de Celanova..., Tomo I, págs. 377-385.

${ }^{137} \mathrm{O}$ estudo mais completo sobre o tema encontra-se em: M. R. GARCia Álvarez, "La batalla de Aguioncha...", págs. 5-41. No entanto, sobre o documento em si e respectivo enquadramento, para uma visão de conjunto, ver: Carlos Balĩ̃as Pérez, Gallegos del Año Mil, Coruña, Fundación Pedro Barrié de la Maza, 1998 (Galicia Histórica), págs. 231-260.
} 
Não nos iremos deter nos seus detalhes ${ }^{138}$, mas somente salientar o recorrente interesse da abadessa do mosteiro de Pazó, Guntroda, parente de Rodrigo Vasques, na apropriação deste cenóbio, e no pedido de ajuda à condessa Mumadona Dias, por parte do diácono Odoíno, seu proprietário.

Mumadona, sob certas condições, e com a ajuda dos seus filhos, Gonçalo e Ramiro Mendes, aceita patrocinar Odoíno, que, no seguimento desse mesmo patrocínio, irá reaver a sua igreja, ocupada pela inefável Guntroda ${ }^{139}$, ...Munmudomna cum filiis suis et concilium ut venisset Gundisalvo Menendiz et Ranemirus Menendiz ad ipsam domna Gunterotem et volens nolens dedisset casam alienam quam iniuste et sine veritate tenebat, sicut et domno promittente factum est $t^{140}$.

Irá ser no seguimento deste envolvimento da família de Gonçalo Mendes, e como já dito em parágrafos anteriores, sem conhecermos, de facto, as suas razões objectivas, irá ter lugar a alphetena de Aguioncha, levando a uma certa descompressão do antagonismo que vinha lavrando entre as Casas condais ali protagonistas e marcando de forma indelével a supremacia do conde portucalense no seio da nobreza galaico-portuguesa, pois alguns dos apoios arregimentados por Rodrigo desertaram na vertigem da confrontação armada, ...ipse Gundisalvus cum suis satellitibus et cum multis qui cum ipso Ruderico erant et ei verba mentiosa dabant... ${ }^{141}$.

Mais a Sul, e igualmente em data não especificada ${ }^{142}$, iremos ver novo choque bélico entre membros da aristocracia galega, desta vez, entre Gonçalo Mendes e Gonçalo Moniz, o conde de Coimbra.

O pretexto, diz-nos um documento já tardio, será um ataque (fossado) levado a efeito por Gonçalo Moniz às possessões do mosteiro de Guimarães e cujo provável epílogo foi o já assinalado choque bélico com as forças de Gonçalo

\footnotetext{
${ }^{138}$ Carlos Baliñas relata-nos com alguma precisão todos os acontecimentos em redor do que é narrado no documento pelo diácono Odoíno. C. BaliÑas Pérez, Gallegos del Año Mil..., págs. 231-260.

${ }^{139}$ Numa data não inteiramente especificada, e igualmente com o intuito de fortalecer patrimonialmente o mosteiro de Pazó por si fundado, Guntroda, a pretexto de ser a protectora da herdeira do mosteiro da Ribeira, irá despojar o citado mosteiro de todo o património móvel e humano. O Tombo de Celanova..., Tomo I, págs. 403-406.

${ }^{140}$ Documento 265, 1 de Outubro de 982 in J. M. Andrade Cernadas, O Tombo de Celanova..., Tomo I, pág. 380 .

${ }^{141}$ Documento 265, 1 de Outubro de 982 in J. M. Andrade Cernadas, O Tombo de Celanova..., Tomo I, pág. 381 .

${ }^{142}$ M. Ruben Garcia Álvarez, "Las Diócesis Galaico-Portuguesas y la política de Almanzor”, Bracara Augusta, Tomo XXI, fascículos 47-48 (1968), pág. 6 e nota 13 e 14, apresenta-nos uma cronologia de largo espectro para esta contenda, entre 951 e 966, baseado na opinião de Fr. Justo PéreZ DE Urbel, Historia del Condado de Castilla, tomo II, Madrid, Consejo Superior de Investigaciones Científicas-Escuela de Estudios Medievales, 1945, pág. 637-638. Este último afirma que após a morte de Sancho I estes dois condes já teriam feito as pazes, sem, no entanto, apresentar uma argumentação consistente. Avançamos, pois, com cautela para a definição temporal de tal momento.
} 
Mendes, vinculado à defesa do dito mosteiro ${ }^{143}$, ... villa uocitata Tauoadelo quos fuit de comes domno Gundisaluo menendi sicut illa obtinui ipse dux magnus in uita sua per consensum monacus et fratres et sorores de cenobio vimaranes ...qui dedit mandamento de tauoadelo ad ipso comite in tempore quando abuit alphetena cum gundisaluo muniuz ... in sacto mames ad defendendum ipsa terra et casa de vimaranes... ${ }^{144}$.

Como se disse, não possuímos uma cronologia assertiva para enquadrar este acontecimento e a data proposta por García Álvarez, de largo espectro, é demasiado ambígua. No entanto, sabemos que em finais de 981 estes dois magnates e respectivas famílias já estariam conciliadas, pois, encontravam-se em Lorvão a confirmar em conjunto vários diplomas ${ }^{145}$.

Assim, encontramos no primeiro documento de Dezembro de $981^{146}$, para além dos bispos de Coimbra, Viseu e Lamego, Gonçalo Moniz e respectiva mulher; Fernando Guterres e Osório Oveques, sobrinho e neto deste último ${ }^{147}$, Telo Alvites e Mendo Gonçalves, primo e filho de Gonçalo Mendes, e outros de difícil identificação (Rodesindus frenandiz e Tedon suariz).

Num próximo documento, igualmente de Dezembro de $981^{148}$, observamos, os bispos de Coimbra, Viseu e Lamego, Bermudo, filho de Ordonho III, os já mencionados Telo Alvites e Mendo Gonçalves, Tedon Aldretiz ${ }^{149}$ e outros (Gutierre didaz, Rodorigo sarraziniz, Gundisaluo aluariz e Gundisaluo didaz), a confirmarem uma doação de Gonçalo Mendes ao já citado mosteiro de Lorvão.

\footnotetext{
${ }^{143}$ Documento XCVII, Dezembro de 968 in Portugalia Monumenta Historica, Diplomata et Chartae, I, pág. 61.

${ }^{144}$ Documento CCCXL, Março de 1045 in Portugalia Monumenta Historica, Diplomata et Chartae, II, págs. 207-208.

${ }^{145}$ Documento CXXX, Dezembro de 981 in Portugalia Monumenta Historica, Diplomata et Chartae, I, pág. 80; Documento CXXXII, Dezembro de 981 in Portugalia Monumenta Historica, Diplomata et Chartae, I, págs. 81-82 e Documento CXXXIII, Dezembro 981 in Portugalia Monumenta Historica, Diplomata et Chartae, I, pág. 82.

${ }^{146}$ Documento CXXX, Dezembro de 981 in Portugalia Monumenta Historica, Diplomata et Chartae, I, pág. 80 .

${ }^{147}$ De facto, esta consideração não está de todo assegurada. Ver considerações em: J. MATtoso, “As Famílias Condais...", pág. 122.

${ }^{148}$ Documento CXXXII, Dezembro de 981 in Portugalia Monumenta Historica, Diplomata et Chartae, I, págs. 81-82.

${ }^{149}$ Não possuímos muitas informações sobre este membro da aristocracia galega. Sabemos que pouco antes (em Outubro de 981) encontrava-se em Samos na companhia de Bermudo Ordonhes (Veremudus, prolis Ordonius rex) a confirmar uma doação de um neto de Bermudo Lucidis, filho de Lucidio Vimaranes, a esse mesmo mosteiro. Documento 27, 11 de Outubro de 981 in Manuel LuCAs Álvarez, El Tumbo de San Julián de Samos (siglos VIII-XII), Estudio introductorio. Edición diplomática. Apéndices e índices, Santiago de Compostela, Caixa Galicia, 1986, págs. 112-113.
} 
E finalmente, no último documento desta série ${ }^{150}$, encontramos Gonçalo Moniz, Soeiro Sandines (cujos ascendentes remontam a Ero Fernandes ${ }^{151}$ ), Mendo e Rodrigo Gonçalves e outros membros de famílias de menor expressão, como Suario Erotiz e Pelagio Liedroniz.

Esta presença de membros das Casas condais portucalense e conimbricense, e demais satélites de difícil identificação ${ }^{152}$, proporciona-nos um acontecimento de importância capital no desenvolvimento futuro do reino astur-leonês, pois será num destes documentos ${ }^{153}$ que o filho de Ordonho III se intitula pela primeira vez rei, Veremudus rex. Há, de certa maneira, no comportamento deste conjunto de nobres, cuja partilha do espaço físico anos antes seria pouco provável, um claro incentivo a esta tomada de posição conflictuante com Ramiro III.

Será, portanto, nesta sedição da aristocracia galega do Sul do Minho em Dezembro de 981, arrastando posteriormente as outras famílias das zonas mais setentrionais, que menos de um ano depois, a 15 de Outubro de 982, Bermudo II será ungido rei na catedral de Santiago, ... et regem alium nomine Veremudum super se erexerunt qui fuit ordinatus in sede sancti Iacobi apostoli idus Octobris, era millesima vicessima ${ }^{154}$.

Em relação ao motivo concreto que levou a esta ruptura, Sampiro informanos que as atitudes e palavras de Ramiro III indispunham os condes galegos. De facto, nada mais relevante é assinalado nas fontes cronísticas coevas, no entanto, através da documentação podemos observar alguns indícios que nos permitem obter mais dados sobre essa "indisposição" que nos fala Sampiro.

Sabemos que o crescimento do património imobiliário da aristocracia e, de certa maneira, a sua posterior preservação, dependem dos favores régios proporcionados pela proximidade e pela lealdade ao monarca e olhando para o percurso documental de Ramiro III ${ }^{155}$ podemos inferir uma clara simpatia pela região leonesa, nomeadamente, pelo mosteiro de Sahagún.

Assim, de um total de vinte documentos ${ }^{156}$ régios, somente quatro dizem respeito à antiga Gallecia ${ }^{157}$, sobretudo, aos mosteiros de Celanova e Sobrado,

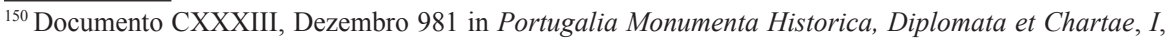
pág. 82 .

${ }^{151}$ J. MAтtoso, “As Famílias Condais...”, págs. 127-135.

${ }^{152}$ No entanto, podemos observar na documentação presente na Portugalia Monumenta Historica vários membros destas famílias com amplas propriedades na região Entre-Minho-e-Mondego.

${ }^{153}$ Documento CXXXII, Dezembro de 981 in Portugalia Monumenta Historica, Diplomata et Chartae, I, págs. 81-82.

${ }^{154}$ Historia Silense, edição preparada por Francisco Santos Coco, pág. 57.

${ }^{155}$ M. Lucas Álvarez, “Cancillerías Reales...”, págs. 342-345.

${ }^{156}$ Dessa resenha documental excluímos os que foram considerados falsos pelos seus editores, estando nesta contagem os documentos suspeitos e, naturalmente, os demais.

${ }^{157}$ Documento 92, 1 de Março de 968 in J. M. Andrade Cernadas, O Tombo de Celanova ..., Tomo I, págs. 140-141 (embora este documento seja na realidade uma doação da regente Elvira, entre os confirmantes
} 
sendo que, destes quatro, dois serão somente confirmações de anteriores privilégios e propriedades ${ }^{158}$. Em termos de documentos particulares, onde o rei apenas apensa a sua assinatura, possuímos um total de vinte e sete documentos ${ }^{159}$, dos quais dez ${ }^{160}$ emanam da região galega, concretamente dos mosteiros de Samos e Celanova. Nota-se, contudo, uma ausência quase ${ }^{161}$ total para a região a Sul do Minho, especificamente, Guimarães e Lorvão.

Neste ponto, a análise documental resvala para uma situação pouco uniforme neste distanciamento face à figura régia por parte de alguns sectores galegos, laicos e eclesiásticos, pois e apesar do seu reduzido séquito, iremos encontrar por estes dias Ramiro III amiúde na região de Lugo, concretamente em Samos.

Observamos, no entanto, somente a presença de membros do clero na sua companhia, particularmente os bispos das dioceses galegas de maior relevo ${ }^{162}$.

A par desta realidade documental, os seus principais apoios nobiliárquicos centram-se no Leste, entre as Casas de Monzón, com o conde Fernando Ansúrez, irmão da sua mãe; entre os condes de Saldanha, como os irmãos Fernando e Osório

encontra-se Ranemirus Rex prolis domni Sanctioni principis cfr); Documento 107, 17 de Setembro de 968 in P. Loscertales de Valdeavellano, Tumbos del Monasterio de Sobrado de los Monjes..., vol. I, Tumbo Primero, págs. 127-130; Documento 206, 21 de Março de 977 in J. M. Andrade Cernadas, O Tombo de Celanova..., Tomo I, págs. 292-293 e Documento 108, 18 de Julho de 978 in Pilar LoscerTALES de Valdeavellano, Tumbos del Monasterio de Sobrado de los Monjes, vol. I, Tumbo Primero, pág. 130. ${ }^{158}$ Documento 206, 21 de Março de 977 in J. M. Andrade Cernadas, O Tombo de Celanova..., Tomo I, págs. 292-293 e Documento 108, 18 de Julho de 978 in P. Loscertales de Valdeavellano, Tumbos del Monasterio de Sobrado de los Monjes..., vol. I, Tumbo Primero, pág. 130.

${ }^{159}$ M. Lucas Álvarez, “Cancillerías Reales...”, págs. 467-471.

${ }^{160}$ Documento 248, 17 de Maio de 960 in M. Lucas Álvarez, El Tumbo de San Julian de Samos..., págs. 431-434; Documento LXXXIV, Novembro de 961 in Portugalia Monumenta Historica, Diplomata et Chartae, I, pág. 53; Documento 42, 27 de Fevereiro de 961 in M. Lucas Álvarez, Tumbo A de la Catedral de Santiago, págs. 114-116; Documento S7, 23 de Dezembro de 969 in M. LuCAs Álvarez El Tumbo de San Julian de Samos (siglos VIII-XII), págs. 451-452; Documento 61, 3 de Junho de 976 in M. LuCAS Álvarez, El Tumbo de San Julián de Samos..., págs. 175-178; Documento 1, 17 de Janeiro de 977 in J. M. Andrade Cernadas, O Tombo de Celanova..., Tomo I, págs. 3-7; El Tumbo de San Julián de Samos, documento 132, 25 de Fevereiro de 978, págs. 288-290; Documento 115 e 199, 30 de Março 982 in M. Lucas Álvarez, El Tumbo de San Julián de Samos..., págs. 258-261 e págs. 375-377; Documento 153, 9 de Dezembro de 982 in M. Lucas Álvarez, El Tumbo de San Julián de Samos..., págs. 318-320 (a respectiva data é somente uma conjectura dos vários editores deste documento, no entanto, o seu conteúdo encontra-se plenamente justificado. Ver nota na pág. 318) e, finalmente, o Documento 156, 983 in M. Lucas Álvarez El Tumbo de San Julián de Samos..., págs. 323-324.

${ }^{161}$ Não será uma ausência total, pois, em data incerta Ramiro III confirma uma anterior doação de Inderquina Pala ao mosteiro de Lorvão em Novembro de 961 (Documento LXXXIV, Novembro de 961 in Portugalia Monumenta Historica, Diplomata et Chartae, I, pág. 53).

${ }^{162}$ Nomeadamente os bispos Gonçalo de Astorga, Bermudo de Oviedo e Pelayo de Iria no Documento 115 e 199, 30 de Março 982 in M. Lucas Álvarez, El Tumbo de San Julián de Samos..., págs. 258-261 e págs. 375-377 e vários bispos entre os quais, Viliulfo de Tui, Armentario de Dume, Paio de Iria e Froilán de Lugo no Documento 153, 9 de Dezembro de 982 in M. Lucas Álvarez, El Tumbo de San Julian de Samos..., págs. 318-320. 
Dias; o conde de Luna, Gonçalo Bermudes ${ }^{163}$, e ainda que com certos objectivos particulares e conjunturais, os condes de Castela, notando-se uma certa distância da generalidade da nobreza galega.

Este panorama reflecte-se no último documento galego que atesta a presença de Ramiro III nessas terras, onde o mesmo se encontra em Samos ${ }^{164} \mathrm{em} 983$ acompanhado de um nutrido séquito, em claro contraste com os documentos do ano de 982, como vimos; onde sobressaem, para além dos bispos Gonçalo e Sebastião, Fernando Dias, conde de Saldanha, o seu irmão Osório Dias e Gonçalo Bermudes.

Poderemos situar, e certamente como consequência da presença destes magnates orientais, a confrontação armada com os partidários de Bermudo II em Portela de Arenas, perto de Lugo, e que marcará, de certa maneira, o final do reinado de Ramiro III, Rex vero Veremudus obviam illi exivit in Portella de Arena, et ceperunt acriter preliari. Nullus tandem eorum alteri cedens, separati sunt ab invicem ${ }^{165}$.

Este ambiente de animosidade interna será certamente potenciado pelos acontecimentos bélicos que vinham marcando as relações do reino com os seus vizinhos muçulmanos, como a campanha de Gormaz em 975 liderada pelo conde castelhano e que se saldaria por uma derrota; no saque de Zamora em Agosto de 981; pelo primeiro ataque à própria capital em 982 e pela campanha muçulmana vitoriosa sobre Simancas e Rueda em $983^{166}$.

Nessa mesma fronteira a Sul desenrolavam-se, desde há uns anos, vários acontecimentos políticos, económicos e sociais, protagonizados por Abu Amir, hachib do califa Hisam II, que viriam a assegurar uma hegemonia das armas muçulmanas sobre os estados cristãos, aproveitando certamente os vários conflitos aristocráticos, bem como, a fragilidade régia derivada dessa conjuntura.

Em jeito de conclusão, e para finalizarmos este artigo que, de certo modo, já se encontra extenso, podemos dizer que, e apesar de todas as divisões entre as várias famílias aristocráticas da antiga Gallecia, sempre existiu uma estreita simbiose entre os seus membros e a coroa, pois ambos estariam inter-dependentes na manutenção dos seus particularismos com vista a assegurarem a respectiva influência política e social no seio do reino.

\footnotetext{
${ }^{163}$ V. Álvarez Palenzuela, "La Nobleza del reino de León...”, págs. 224-225.

${ }^{164}$ Documento 156, 983 in M. Lucas Álvarez, El Tumbo de San Julián de Samos..., págs. 323-324.

${ }^{165}$ Historia Silense, edición preparada por Francisco Santos Coco, pág. 57.

${ }^{166}$ Vicente Álvarez Palenzuela defende, com alguma verosimilhança, que fora após o desaire de Rueda que se dará o confronto em Portela de Arenas, em finais de 983. V. Álvarez Palenzuela, "La Nobleza del reino de León...”, págs. 225-226.
} 
La estirpe de Diego Fernández

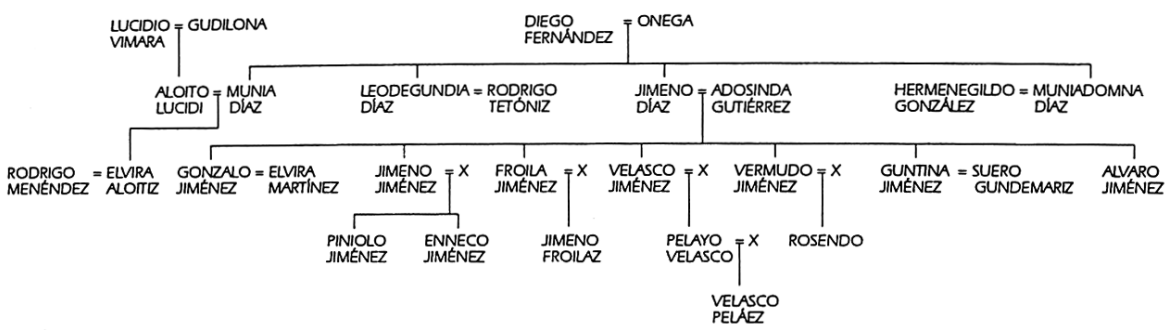

Figura 1. Genealogia da família de Diogo Fernandes (Adaptado de: Vicente Álvarez Palenzuela, "La Nobleza del Reino de León en la Alta Edad Media", in El Reino de León en la Alta Edad Media, vol. VII, León, Centro de Estudios e Investigación "San Isidoro", 1988

(Fuentes y Estudios de Historia Leonesa, núm. 58), pág. 307).

El Conde Gatón. La estirpe de Hermenegildo Gutiérrez

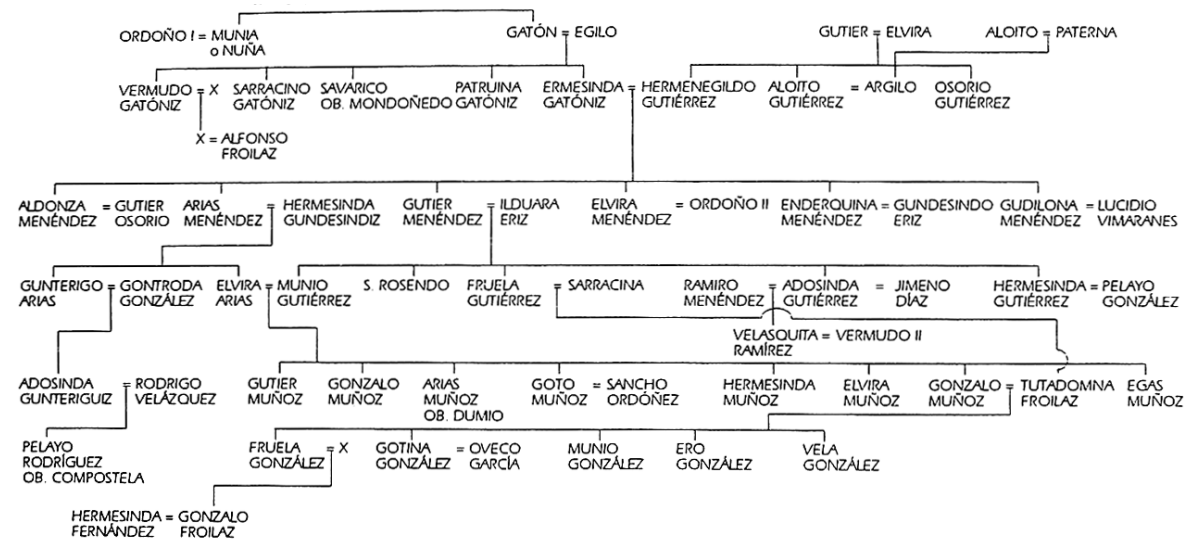

Figura 2. Genealogia do conde Gatão. Estirpe de Hermenegildo Guterres (Adaptado de: V. Álvarez Palenzuela, "La Nobleza del Reino de León...”, pág. 299). 
La familia de Rodrigo Velázquez

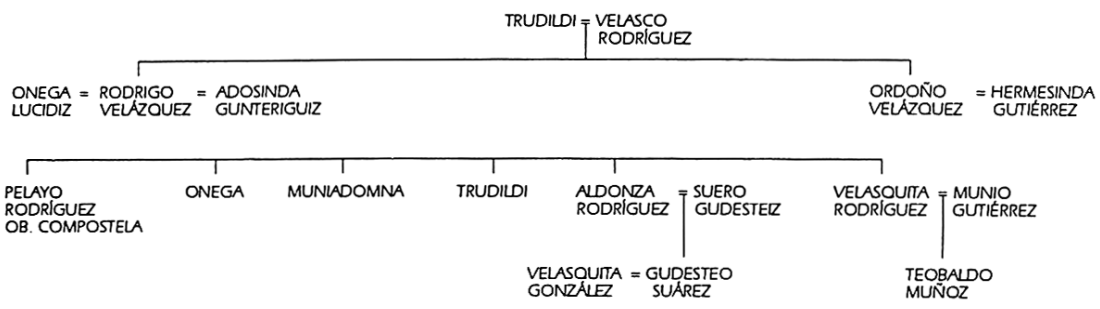

Figura 3. Genealogia da família de Rodrigo Velázquez

(Adaptado de: V. Álvarez Palenzuela, "La Nobleza del Reino de León...”, pág. 311).

Pedro Theón y Vimara Pérez

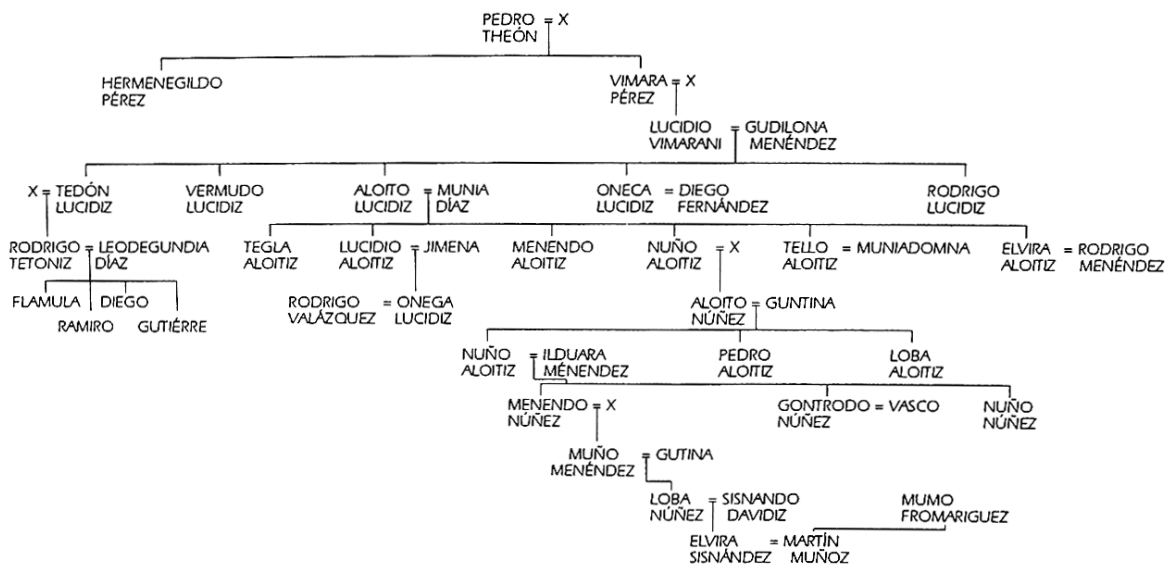

Figura 4. Genealogia da família de Vímara Peres

(Adaptado de: V. Álvarez Palenzuela, “La Nobleza del Reino de León...”, pág. 301). 
La familia del Conde Osorio

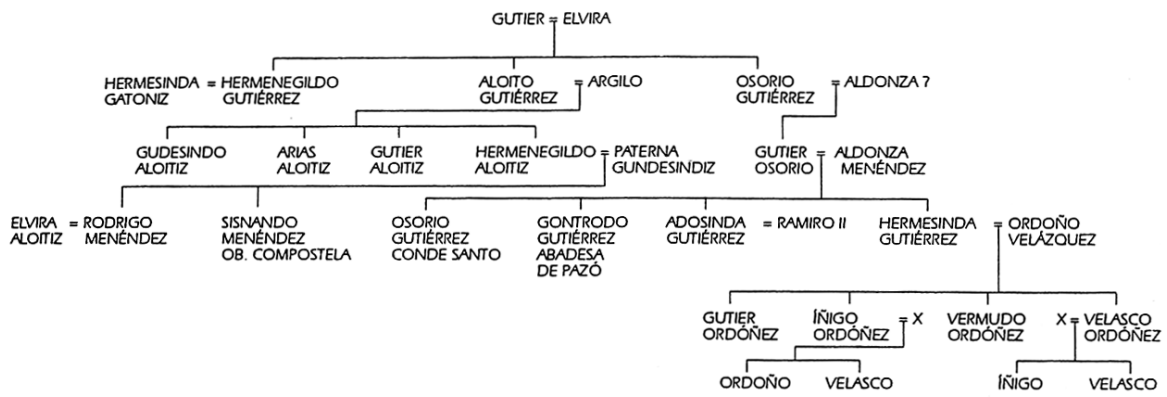

Figura 5. Genealogia da família do conde Osório

(Adaptado de: V. Álvarez Palenzuela, “La Nobleza del Reino de León...”, pág. 300).

La familia del Conde Osorio

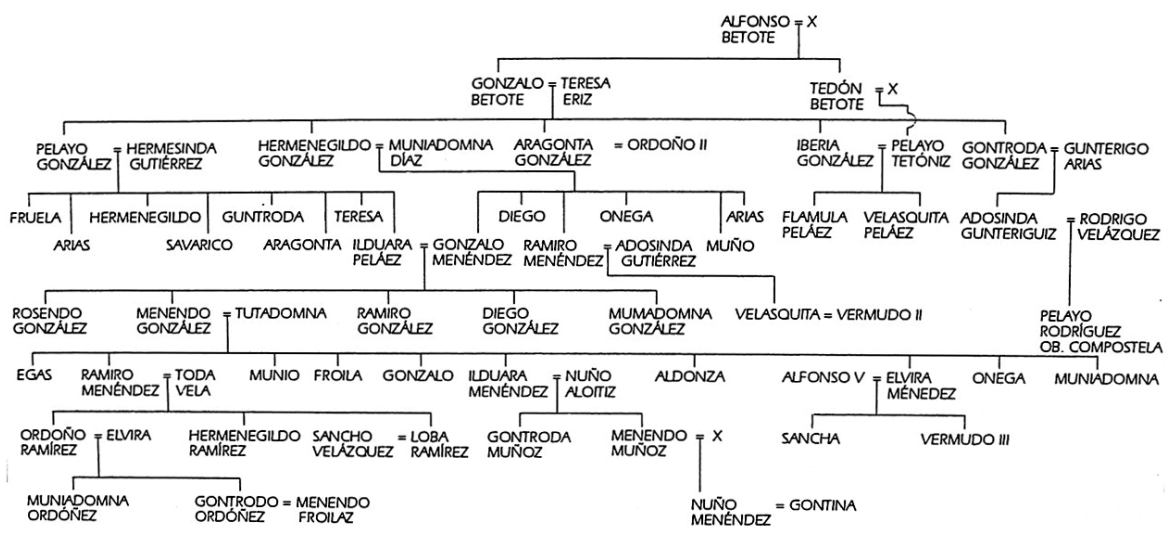

Figura 6. Genealogia das famílias Betote e Mendes

(Adaptado de: V. Álvarez Palenzuela, “La Nobleza del Reino de León...”, pág. 305). 


\section{BIBLIOGRAFIA}

Al-Makkari, The History of the Moammedan Dynasties in Spain, vol. II, tradução de Pascual de Gayangos, Londres, 1843.

Álvarez Palenzuela, Vicente, "La Nobleza del Reino de León en la Alta Edad Media", in El Reino de León en la Alta Edad Media, vol. VII, León, Centro de Estudios e Investigación San Isidoro - Archivo Historico Diocesano, 1988 (Fuentes y Estudios de Historia Leonesa, 58), págs. 149-329.

Andrade Cernadas, José Miguel, O Tombo de Celanova: Estudio Introductorio, Edición e Índices (ss. IX-XIII), Santiago de Compostela, Consello de Cultura Galega, 1995, 2 vols.

Azevedo, Luís Gonzaga de, História de Portugal, volume II, Lisboa, Edições Bíblion, 1939.

Azevedo, Rui Pinto de "A expedição de Almançor a Santiago de Compostela em 997, e a de piratas normandos à Galiza em 1015-16", Revista Portuguesa de História, Tomo XIV (1973), págs. 73-93.

Baliñas Pérez, Carlos, Gallegos del Ano Mil, Colección Galicia Histórica, Coruna, Fundación Pedro Barrié de la Maza, 1998 (Colección Galicia Histórica).

Carriedo Tejedo, Manuel, "Sisnando II de Santiago (951-968): Totius orbis antistes”, Compostellanum, vol. LVIII, núms. 3-4 (2013), págs. 543-606.

Coco, Francisco Santos, Historia Silense, Edición, Madrid, Junta para la Ampliación de Estudios e Investigaciones Científicas. Centro de Estudios Históricos, 1921.

Ferreira, Maria do Céu e Lobão, João Carlos, "Arqueologia no castelo de Trancoso: novos dados para o estudo da fortificação", in Isabel Cristina F. Fernandes (coord.), Fortificações e Território na Península Ibérica e no Magreb (Séculos VI a XVI), vol. II, Lisboa, Edições Colibri-Campo Arqueológico de Mértola, 2013, págs. 761-771.

García Álvarez, M. Rubén, "El Gallego Ordono III, Rey de León”, Cuadernos de Estudios Gallegos, tomo XXII, núm. 68 (1967), págs. 281-335.

García Álvarez, M. Rubén, "Jimeno Díaz y Adosinda Gutiérez”, Bracara Augusta, Tomo XXXII, fascículos 73-74 (1978), págs. 143-180.

García Álvarez, M. Rubén, "La Batalla de Aguioncha: Una guerra civil galaico-portuguesa del siglo X”, Bracara Augusta, Tomo XX, fascículos 45-46 (1967), págs. 307-342.

García Álvarez, M. Rubén, "La Reina Velasquita, nieta de Muniadmna Diaz?”, Revista de Guimarães, 70 (1-2) (1960), págs. 197-231.

García Álvarez, M. Rubén, "Las Diócesis Galaico-Portuguesas y la política de Almanzor", Bracara Augusta, Tomo XXI, fascículos 47-48 (1968), págs. 38-54.

García Álvarez, M. Rubén, "Ordono IV de León, un rey impuesto por Castilla”, Archivos Leoneses, 42 (Julio-Diciembre.1967), págs. 1-46.

García Álvarez, M. Rubén, "Un Documento Interessante para la Historia de Galicia”, Cuadernos de Estudios Gallegos, tomo XIX, núm. 59 (1964), págs. 355-368.

Gouveia, Mário de, "Hermenegildo Guterres e a presúria de Coimbra (séc. IX-X)", in Olhares sobre a História. Estudos oferecidos a Iria Gonçalves, Lisboa, Caleidoscópio, 2009, págs. 279-292.

Isla Frez, Amancio, Ejército, Sociedad y Política en la Península Ibérica entre los Siglos VII y XI, Madrid, Ministerio de Defensa-Consejo Superior de Investigaciones Científicas, 2010. 
Isla Frez, Amancio, La Sociedad Gallega en la Alta Edad Media, Madrid, Consejo Superior de Investigaciones Científicas, 1992.

Isla Frez, Amancio, "Nombres de Reyes y Sucesión al trono (Siglos VIII-X)", Studia Historica - Historia Medieval, 11 (1993), págs. 9-33.

Isla Frez, Amancio, Realezas Hispánicas del Año Mil, Sada, Ediciós do Castro, 1999.

Loscertales de Valdeavellano, Pilar, Tumbos del Monasterio de Sobrado de los Monjes, vol. 1, Tumbo Primero, Madrid, Dirección Geral del Património Artistico y Cultural-Archivo Histórico Nacional, 1976.

Lucas Álvarez, Manuel, El Tumbo de San Julián de Samos (siglos VIII-XII), Estudio introductorio. Edición diplomática. Apéndices e índices, Santiago de Compostela, Caixa Galicia, 1986.

Lucas Álvarez, Manuel, "La documentación Real Astur-Leonesa (718-1072)", in El Reino de León en la Alta Edad Media, vol. VIII, León, Centro de Estudios e Investigación San Isidoro-Archivo Histórico Diocesano de León, 1995 (Fuentes y Estudios de Historia Leonesa, 57), págs. 17-709.

Lucas Álvarez, Manuel, Tumbo A de la Catedral de Santiago. Estudio y Edición, Santiago, Seminario de Estudos Galegos-Cabildo de la S.A.M.I. Catedral, 1998.

Martín, José-Luis, "Pelayo Rodríguez, Obispo de Santiago (977-985)", Anuario de Estudios Medievales, vol. 2 (1965), págs. 467-475.

Martínez, Virgilio; Torremocha, Antonio, Almanzor y su época. Al-Andalus en la segunda mitad del siglo X, Málaga, Editorial Sarriá, 2001.

Mattoso, José, "As Famílias Condais Portucalenses dos Séculos X e XI", in A Nobreza Medieval Portuguesa. A Família e o Poder, Lisboa, Editorial Estampa, 1981, págs. 103-159.

Mattoso, José, "Portugal no reino Astur-Leonês", in José Mattoso (dir.), História de Portugal, vol. 1, Lisboa, Círculo de Leitores, 1992, págs. 439-565.

Meouak, Mohamed, "La Biographie de Galib, haut functionnaire andalou de l'époque califale: carrière politique et titres honorifiques”, Al-Qantara, vol. XI, I (1990), págs. 95-112.

Merêa, Paulo, De "Portucale" (civitas) ao Portugal de D. Henrique, Porto, Portucalense Editora, 1954.

Mínguez, José Maria, Colección Diplomática del Monasterio de Sáhagun (siglos IXy X), León, Centro de Estudios e Investigación San Isidoro-Archivo Histórico Diocesano de León, 1976 (Fuentes y Estudios de Historia Leonesa, 17).

Pires, Hélio, Incursões Nórdicas no Ocidente Ibérico (844-1147): Fontes, História e Vestígios. Dissertação de Doutoramento policopiada, 2012.

Portela Silva, Ermelindo e Pallares Méndez, María del Carmen, "Elementos para el Analisis de la Aristocracia Altomedieval de Galicia: Parentesco y Patrimonio", Studia Historica Historia Medieval, 5 (1987), págs. 17-32.

Portugaliae Monumenta Historica. Diplomata et Chartae, I, II e III, Lisboa, Academia das Ciências de Lisboa, 1868, 1869 e 1870.

Real, Manuel Luís, "O castro de Baiões terá servido de atalaia ou castelo na Alta Idade Média? Sua provável relação com o refúgio de Bermudo Ordonhes na Terra de Lafões", Revista da Faculdade de Letras, Série Ciências e Técnicas do Património, vol. XII (2013), págs. 203-230. 
Rodríguez, Justiniano, "Gonzalo Munoz, Dux de Terra Portucalense”, in Actas das II Jornadas Luso-Espanholas de História Medieval, vol. I, Porto, Centro de História da Universidade do Porto-Instituto Nacional de Investigação Cientifica, 1987, págs. 111-121.

Rodríguez, Justiniano, "La Monarquía Leonesa. De García I a Vermudo III”, in El Reino de León en la Alta Edad Media, vol. III, León, Centro de Estudios e Investigación San Isidoro-Archivo Historico Diocesano, 1995 (Fuentes y Estudios de Historia Leonesa, 50), págs. 131-413.

Rodríguez, Justiniano, "Ramiro II, Rey de León”, Estudios, vol. XL, Madrid, Consejo Superior de Investigaciones Científicas-Escuela de Estudios Medievales, 1972.

Sáez, Emilio, Colección Documental del Archivo de la Catedral de León (775-1230), I (775952), León, Centro de Estudios e Investigación San Isidoro-Archivo Histórico Diocesano de León, 1987 (Fuentes y Estudios de Historia Leonesa, 41).

Sáez, Emilio; Sáez, Carlos, Colección Documental del Archivo de la Catedral de León (7751230), II (953-985), León, Centro de Estudios e Investigación San Isidoro-Archivo Histórico Diocesano de León, 1990 (Fuentes y Estudios de Historia Leonesa, 42).

Sáez, Emilio, "Los Ascendientes de San Rosendo. Notas para el estudio de la monarquia Astur-Leonesa durante los siglos IX y X”, Hispania, núm. XXX (1948), págs. 7-133.

Sáez, Emilio, "Notas al Episcopologio Minduniense del Siglo X”, Hispania, núm. XXII (1947), págs. 7-83.

Sáez, Emilio, "Notas y Documentos sobre Sancho Ordonez Rey de Galicia", Cuadernos de Historia de España, vol. XI (1949), págs. 25-92.

Sáez, Emilio, "Ramiro II, rey de Portugal de 926 a 930", Revista Portuguesa de História, tomo III (1945), págs. 271-290.

Sánchez-Albornoz, Claudio, "La Sucesión al Trono de los Reinos de Leon y Castilla", in Viejos y Nuevos Estudios sobre las Instituiciones Medievales Españolas, Tomo II, 2a edição, Madrid, Espasa-Calpe, 1976, págs. 1107-1165.

Serrano, Luciano (ed.), Becerro Gótico de Cardena, Valladolid, Cuesta, 1910

Tente, Catarina, "Viver em autarcia. A organização do território do Alto Mondego (Portugal) entre os séculos V a X", in Inaki Martin Viso (ed.), ¿Tiempos Oscuros? Territorios y Sociedad en el Centro de la Península Ibérica (siglos VII-X), Madrid; Salamanca, Sílex; Universidad de Salamanca, 2009, págs. 137-157.

Torres Sevilla-Quiñones de León, Margarita, Linajes nobiliarios en León y Castilla (siglos IX-XIII), Salamanca, Junta de Castilla y León, 1999.

Urbel, Fr. Justo Pérez de, Historia del Condado de Castilla, tomo II, Madrid, Consejo Superior de Investigaciones Científicas-Escuela de Estudios Medievales, 1945.

Urbel, Fr. Justo Pérez de, Sampiro. Su Cronica y la Monarquia Leonesa en el siglo X, Madrid, Consejo Superior de Investigaciones Científicas-Escuela de Estudios Medievales, 1952 (Estudios, vol. XXVI). 
